\title{
Neurobiology of Pavlovian FEAR Conditioning
}

\author{
Stephen Maren \\ Department of Psychology and Neuroscience Program, University of Michigan, \\ Ann Arbor, Michigan 48109-1109; e-mail: maren@umich.edu
}

Key Words learning, memory, amygdala, hippocampus, synaptic plasticity

- Abstract Learning the relationships between aversive events and the environmental stimuli that predict such events is essential to the survival of organisms throughout the animal kingdom. Pavlovian fear conditioning is an exemplar of this form of learning that is exhibited by both rats and humans. Recent years have seen an incredible surge in interest in the neurobiology of fear conditioning. Neural circuits underlying fear conditioning have been mapped, synaptic plasticity in these circuits has been identified, and biochemical and genetic manipulations are beginning to unravel the molecular machinery responsible for the storage of fear memories. These advances represent an important step in understanding the neural substrates of a rapidly acquired and adaptive form of associative learning and memory in mammals.

\section{INTRODUCTION}

To sum up, we may legitimately claim the study of the formation and properties of conditioned reflexes as a special department of physiology.

I. P. Pavlov, 1927

Seventy-five years ago, Ivan Petrovich Pavlov advocated the physiological analysis of the simple form of associative learning that carries his name: Pavlovian or classical conditioning (Pavlov 1927). If Pavlov were alive today, he would most certainly be impressed with the amazing progress we have made in delineating the brain circuits and neuronal mechanisms underlying Pavlovian conditioning in a variety of behavioral systems and species (Holland \& Gallagher 1999, Krasne \& Glanzman 1995, Thompson \& Krupa 1994). One form of Pavlovian conditioning that has received considerable attention in the last 10 years is fear conditioning (Davis 1992, Fendt \& Fanselow 1999, LeDoux 2000, Maren 1996). Simply stated, Pavlovian fear conditioning involves learning that certain environmental stimuli predict aversive events - it is the mechanism whereby we learn to fear people, places, objects, and animals. Evolution has crafted this form of learning to promote survival in the face of present and future threats, and it is an essential 
component of many mammalian defensive behavior systems (Fanselow 1994). Fear conditioning has attracted such great interest in recent years because it is squarely seated at the interface of memory and emotion (LeDoux 2000). Moreover, disturbances in fear conditioning may contribute to disorders of fear and anxiety in humans, such as panic disorder and specific phobias (Rosen \& Schulkin 1998, Wolpe 1981).

John Watson and Rosalie Rayner's famous experiment with the infant, Albert $\mathrm{B}$, is an instructive example of the Pavlovian fear conditioning procedure (Watson \& Rayner 1920). In this experiment Watson and Rayner set out to condition fear to a white rat by sounding a loud and aversive noise after presenting the rat to "Little Albert." Before pairing the white rat with noise, the rat did not evoke fear in Albert (Figure 1A). Not surprisingly, the loud noise, which Watson generated by striking a hammer on a suspended steel bar, produced a robust fear response in Albert. Upon hearing the noise, Albert "startled violently" and "broke into a sudden crying fit." After several pairings of the rat and noise, Albert came to fear the rat. When Watson presented the rat to Albert after conditioning, Albert fell over, cried, and attempted to crawl away from the animal (Figure $1 B$ ). In Watson and Rayner's words, "This was as convincing a case of a completely conditioned fear response as could have been theoretically pictured." Although this experiment nicely illustrates fear conditioning, it is important to note that this type of experiment would not be acceptable by current ethical standards.

Appealing to the semantics of Pavlovian conditioning, Little Albert had learned that an innocuous conditional stimulus (CS; the white rat) predicted the occurrence of a noxious unconditional stimulus (US; the loud noise). Learning was manifest as a conditional response (crying) that, in this case, took the form of the unconditional response that was elicited by the loud noise prior to conditioning. Watson and Rayner's experiment with Albert exemplifies the traditional view of Pavlovian conditioning that one stimulus comes to evoke the response of anotherthe so-called conditioned reflex. However, as Rescorla has powerfully argued, current thinking holds that Pavlovian conditioning involves learning the hierarchical relationships among events (Rescorla 1988). Indeed, Pavlovian conditioning enables organisms to form neural representations of their worlds. Hence, the representation of the relations between aversive or traumatic events and the stimuli that predict them is at the core of Pavlovian fear conditioning.

The aim of this review is to describe recent developments in our understanding of the neurobiological basis of Pavlovian fear conditioning in mammals, including humans. The review focuses on work in rodent models, although data from other mammals and humans is included as necessary. It begins with a brief history of the brain and fear, proceeds with an outline of the neuroanatomical circuitry required for fear conditioning, and concludes with a discussion of the cellular and synaptic mechanisms within that circuitry that are responsible for the formation, storage, and expression of fear memories. 

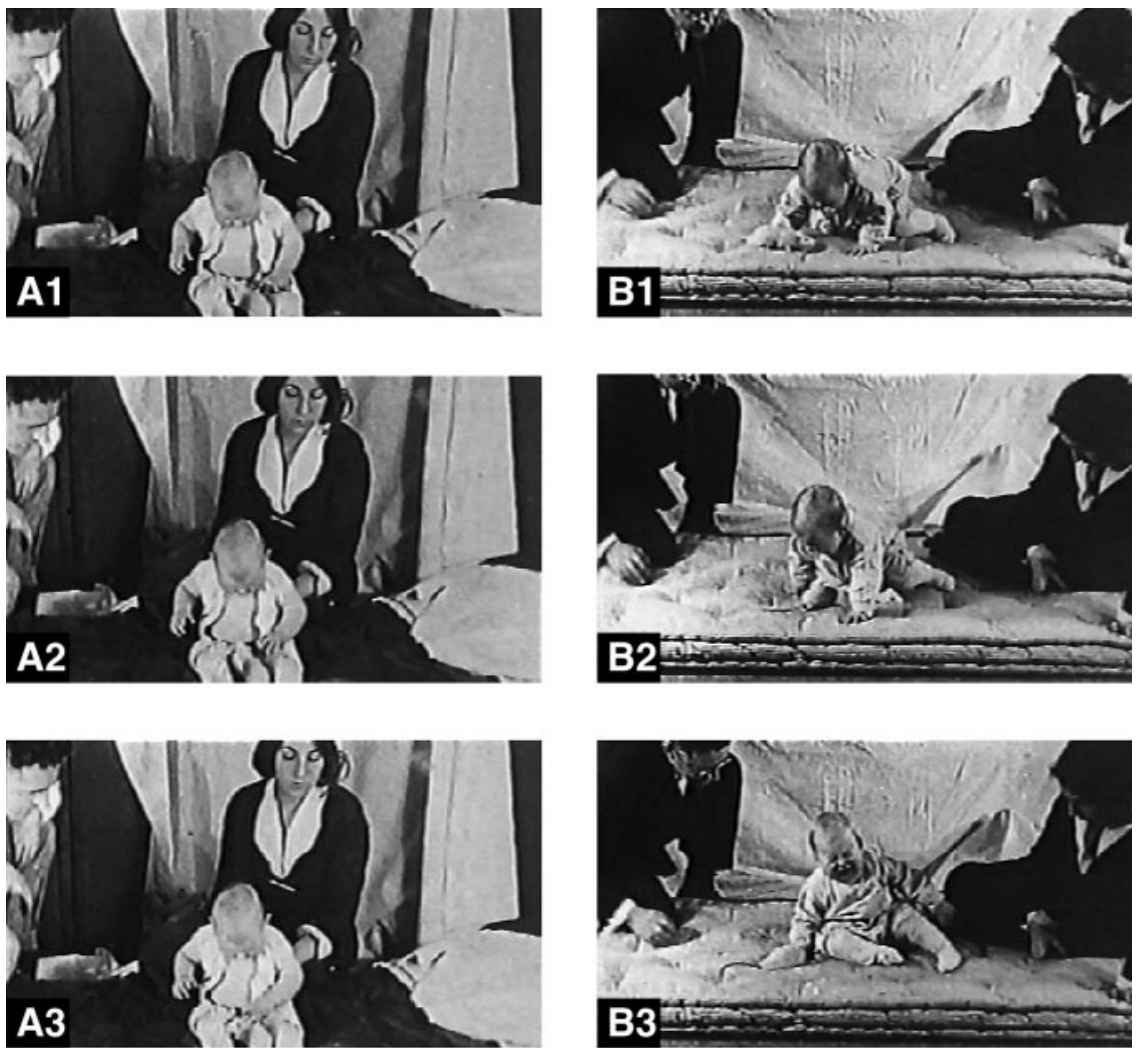

Figure 1 Still frames captured from a film of Watson and Rayner's famous experiment with the infant, Albert B ("Little Albert") (Watson 1920). (A1-A3) Watson presents Albert with a novel white rat. Albert responds with curiosity and reaches out to touch the animal. Although not shown, Watson subsequently paired presentations of the white rat with a loud and aversive noise. (B1-B3) Watson again presents Albert with the white rat after the rat had been paired with the loud noise. Unlike his initial reaction to the rat shown in $A$, Albert now responds to the rat with fear. He moves away from the rat and cries. (Still images courtesy of The Archives of the History of American Psychology, Akron, OH.)

\section{THE BRAIN AND FEAR: HISTORICAL PERSPECTIVES}

Our modern appreciation of the brain circuits involved in fear conditioning emerged from early observations of the effects of brain damage on emotional behavior in animals. In 1888, Brown \& Schäfer (1888) described profound alterations in emotional reactivity following temporal lobe injuries in monkeys. Klüver \& Bucy (1937) elaborated this effect in 1937. Both groups found that temporal lobe resections, which damaged both cortical and subcortical tissue, produced marked 
behavioral changes, including hyperorality, hypersexuality, visual agnosia, and notably, a loss of fear. For example, resected monkeys readily consumed novel and normally avoided foods, such as meat, and they would mouth inedible objects. Moreover, monkeys that once cowered in the presence of humans readily approached and contacted their caretakers after surgery. This work heralded the study of the neural substrates of emotion and focused intense interest on the role of the temporal lobes in the mediation of fear.

Subsequent work by Weiskrantz and others (Weiskrantz 1956, Zola Morgan et al 1991) demonstrated that the loss of fear in monkeys with temporal lobe lesions results from damage to the amygdala, a heterogeneous group of nuclei buried deep within the temporal lobes. Indeed, a recent study confirms that selective excitotoxic damage to amygdala neurons results in a fear reduction similar to that observed by Klüver \& Bucy (Meunier et al 1999). Numerous other studies have demonstrated reduced fear ("taming") after amygdala damage in several mammalian species including rats, cats, rabbits, dogs, and humans (Goddard 1964). Moreover, both electrical stimulation of the amygdala and amygdaloid seizures are associated with autonomic and behavioral changes characteristic of fear (Davis 1992, Gloor 1960). Hence, consensus has emerged from these studies that the amygdaloid complex has an indispensable role in the regulation of fear.

Soon after the discovery of the amygdala's role in fear, several investigators set out to further quantify this function by employing learning and memory tasks. The earliest studies to investigate the involvement of the amygdala in fear-motivated learning used instrumental avoidance tasks, in which animals could avoid an aversive stimulus by making the appropriate behavioral response (Fonberg 1965, Horvath 1963, King 1958, Robinson 1963). For example, Brady and colleagues trained cats in a footshock-motivated shuttle avoidance task and found that large amygdala aspirations impaired the acquisition, but not retention, of the avoidance response (Brady et al 1954). In addition to instrumental learning, Pavlovian fear conditioning has been used to assess the involvement of the amygdala in emotional behavior. For example, Kellicutt \& Schwartzbaum (1963) demonstrated a critical role for the amygdala in the acquisition of a conditioned emotional response, which they indexed by measuring bar-press suppression to a CS previously paired with shock. The Blanchards extended this work by demonstrating a direct role for the amygdala in the acquisition of contextual fear conditioning (Blanchard \& Blanchard 1972), in which animals learn that the situational or contextual cues associated with conditioning predict the occurrence of footshock. Amygdala lesions completely eliminate shock-elicited freezing (somatomotor immobility), as well as unconditional freezing elicited by a predator (a cat) (Blanchard \& Blanchard 1972). These studies established that forms of learning and memory that are motivated by fear require the amygdala.

In recent years several investigators have revealed an important role for the human amygdala in fear conditioning (Davidson \& Irwin 1999). For example, a patient with bilateral amygdala pathology associated with the rare genetic disorder, Urbach-Wiethe disease, does not exhibit Pavlovian fear conditioning to either 
visual or auditory cues paired with loud noise (Bechara et al 1995). Patients who have received a unilateral amygdalectomy for the treatment of epilepsy also have deficits in auditory fear conditioning (LaBar et al 1995), and patients with amygdala damage fail to recognize fear in facial expressions (Adolphs et al 1995, 1999; Young et al 1995). Functional neuroimaging has extended these lesion studies by revealing amygdala activation to visual or vocal expressions of fear (Morris et al 1996, Phillips et al 1997, Whalen et al 1998) and during Pavlovian fear conditioning (Buchel et al 1999, LaBar et al 1998). Thus, the neural mechanisms of fear conditioning appear to exhibit homology across several mammalian species.

\section{NEURAL SYSTEMS FOR FEAR CONDITIONING}

In the light of this work, the analysis of the neural circuitry of fear conditioning has largely concentrated on describing the intrinsic anatomy of the amygdala and mapping the sensory afferents and motor efferents of the amygdala. In the rat the amygdala consists of several anatomically and functionally distinct nuclei, including (but not limited to) the lateral (LA), basolateral (BL), basomedial, and central (CE) amygdaloid nuclei (Brodal 1947, Krettek \& Price 1978). Anatomical and behavioral evidence indicates that these nuclei are components of two distinct subsystems within the amygdala that are important for fear conditioning (LeDoux 1995, Maren \& Fanselow 1996). The first subsystem of the amygdala is comprised of LA, BL, and basomedial. Collectively referred to as the basolateral complex (BLA), these nuclei form the primary sensory interface of the amygdala. Thus, selective lesions of the BLA produce severe deficits in both the acquisition and expression of Pavlovian fear conditioning independent of the stimulus modality used to train fear responses (Campeau \& Davis 1995b, Cousens \& Otto 1998, LeDoux et al 1990, Maren et al 1996a). Within the BLA, the LA appears to be essential for fear conditioning (Amorapanth et al 2000). Selective lesions of the BL do not impair fear conditioning but do attenuate the acquisition of instrumental avoidance behavior (Amorapanth et al 2000). Killcross and colleagues have reported a similar effect, although their lesions encompassed both LA and BL (Killcross et al 1997).

The second subsystem of the amygdala consists of the CE and it constitutes the amygdala's interface to fear response systems. For example, electrical stimulation of CE produces behavioral responses similar to those evoked by stimuli paired with shock (Iwata et al 1987, Kapp et al 1982). Lesions of the CE also produce profound deficits in both the acquisition and expression of conditional fear (Hitchcock \& Davis 1986, Iwata et al 1986, Kim \& Davis 1993, Roozendaal et al 1991, Young \& Leaton 1996), and pharmacological studies suggest that this is due to a deficit in the performance of conditional fear responses, rather than an associative deficit (Fanselow \& Kim 1994, Goosens et al 2000). Moreover, lesions placed in structures efferent to the $\mathrm{CE}$, such as the lateral hypothalamus or periaqueductal grey, produce selective deficits in either cardiovascular or somatic conditional fear responses, respectively (Amorapanth et al 1999, De Oca et al 1998, LeDoux et al 1988). This 
suggests that the $\mathrm{CE}$ is the final common pathway for the generation of learned fear responses.

The major afferent and efferent projection systems of the amygdala that are relevant to fear conditioning are illustrated in Figure 2. For simplicity, this figure shows only unidirectional connections and ignores interconnections between extraamygdaloid structures. It is readily appreciated that the BLA is a locus of convergence of afferents from both subcortical and cortical sensory regions (McDonald 1998, Pitkanen et al 1997, Swanson \& Petrovich 1998). As such, projections from either the auditory thalamus or the auditory cortex to the BLA are essential for conditioning to auditory CSs (Campeau \& Davis 1995a, LeDoux et al 1986, McCabe et al 1993, Romanski \& LeDoux 1992), projections from the hippocampal formation to the BLA underlie conditioning to contextual CSs (Kim \& Fanselow 1992, Maren 1999c, Maren \& Fanselow 1995, Phillips \& LeDoux 1992), and projections from the perirhinal cortex transmit visual CS information to the BLA (Campeau \& Davis 1995a, Rosen et al 1992). Information about the aversive footshock US might reach the BLA via parallel thalamic and cortical pathways (Shi \& Davis 1999). Consistent with this anatomy, single neurons in the BLA respond to auditory, visual, and somatic (shock) stimuli (Romanski et al 1993), which indicates that the amygdala is a locus of convergence for information about CSs and USs. Thus, the BLA is anatomically situated to integrate information from a variety of sensory domains.

Several models posit a role for the BLA in CS-US association during fear conditioning (Davis 1992, Fanselow \& LeDoux 1999, Maren 1999a). In these models it is assumed that direct projections from the BLA to the CE enable associations established in the BLA to elicit fear responses via the CE. Indeed, the CE projects to several diverse brain areas involved in the generation of various fear responses. Hence, amygdala lesions block fear conditioning to contextual (Antoniadis \& McDonald 2000, Maren 1998), auditory (Campeau \& Davis 1995b, LeDoux et al 1990, Maren et al 1996a), olfactory (Cousens \& Otto 1998), and visual CSs (Sananes \& Davis 1992), and these deficits are manifest when one measures freezing (Cousens \& Otto 1998, Maren et al 1996a), defecation (Antoniadis \& McDonald 2000), hypoalgesia (Helmstetter 1992, Watkins et al 1993), potentiated acoustic startle (Campeau \& Davis 1995b), increased heart rate (Antoniadis \& McDonald 2000, LeDoux et al 1990), or corticosterone secretion (Goldstein et al 1996).

\section{Association Formation and the Amygdala}

An important goal of the neurobiological analysis of fear conditioning is to identify the essential substrate for the encoding and storage of fear memories (i.e. CS-US associations). There is now strong evidence that the amygdala, and the BLA in particular, is a locus for the formation and storage of CS-US associations during Pavlovian fear conditioning. This evidence has been obtained from studies employing permanent and reversible lesions of the amygdala and neurophysiological recordings of amygdala spike firing during learning. 


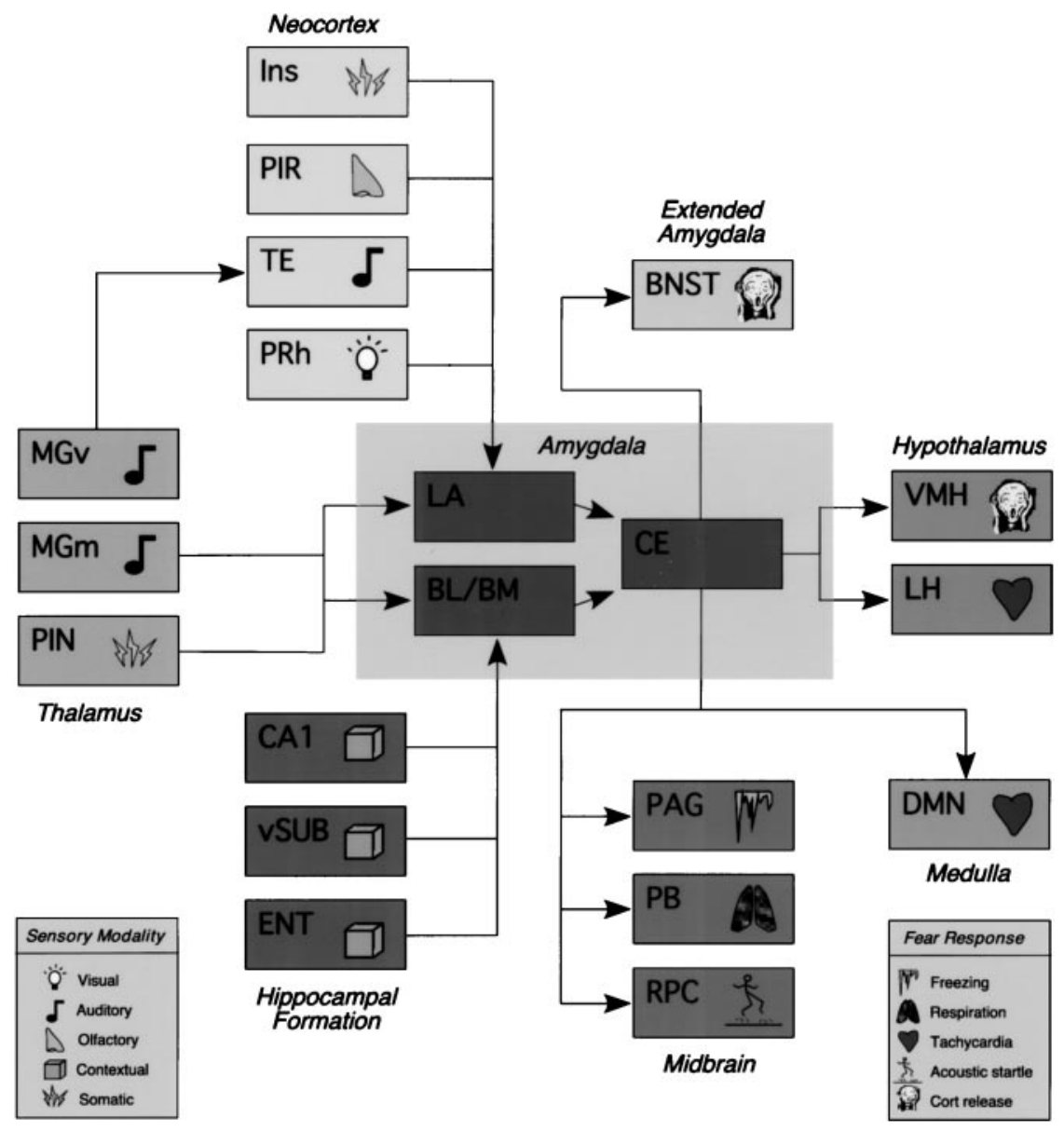

Figure 2 Anatomy of fear conditioning circuits in the brain. The amygdaloid nuclei (shown in the center) can be roughly divided into two subsystems. These include the lateral (LA), basolateral (BL), and basomedial (BM) nuclei, which together form the basolateral complex (BLA) and the central nucleus (CE). The BLA receives and integrates sensory information from a variety of sources. These include the medial and ventral divisions of the thalamic medial geniculate nucleus (MGm and MGv, auditory), the perirhinal cortex (PRh, visual), primary auditory cortex (TE), the insular cortex (INS, gustatory and somatosensory), the thalamic posterior intralaminar nucleus (PIN, somatosensory), the hippocampal formation (spatial and contextual) including area CA1, the ventral subiculum (vSUB), the entorhinal cortex (ENT), and the piriform cortex (PIR, olfactory). Thus, the BLA is a locus of sensory convergence and a plausible site for CS-US association within the amygdala. Intraamygdaloid circuitry conveys the CS-US association to the CE, where divergent projections to the hypothalamus and brainstem mediate fear responses such as freezing (periaqueductal gray, PAG), potentiated acoustic startle (nucleus reticularis ponits caudalis, RPC), increased heart rate and blood pressure (lateral hypothalamus, LH; dorsal motor nucleus of the vagus, $\mathrm{DMN}$ ), increased respiration (parabrachial nucleus, PB), and glucocorticoid release (paraventricular nucleus of the hypothalamus, PVN; bed nucleus of the stria terminalis, BNST). For simplicity, all projections are drawn as unidirectional connections, although in many cases these connections are reciprocal. 
Permanent or Temporary Lesions of the Amygdala Disrupt the Acquisition and Expression of Conditional Fear Selective neurotoxic lesions of the BLA severely attenuate the acquisition of fear conditioning to both contextual and discrete CSs when made before training (Cousens \& Otto 1998, Maren et al 1996a, Sananes \& Davis 1992). Moreover, neurotoxic BLA lesions completely abolish the expression of conditional fear responses when made either shortly after training (Campeau \& Davis 1995b; Cousens \& Otto 1998; Maren 1998, 1999b; Maren et al 1996a), two weeks following training (Cousens \& Otto 1998, Maren et al 1996a), or even up to one month following training (Lee et al 1996, Maren et al 1996a). Posttraining neurotoxic BLA lesions also abolish conditional fear after extensive overtraining (Maren 1998, 1999b). It is important to note that neurotoxic BLA lesions do not affect footshock sensitivity nor do they alter baseline locomotor activity (Campeau \& Davis 1995b, Maren 1998). Neurotoxic lesions of the CE also attenuate the acquisition and expression of fear conditioning (Campeau \& Davis 1995b, Helmstetter 1992), but there is reason to believe that the CE is primarily involved in expressing, as opposed to encoding, CS-US associations (Fanselow \& Kim 1994, Goosens et al 2000).

As mentioned earlier, it is well documented that amygdala damage disrupts not only learned fear, but also innate fear under some conditions. For example, rats with amygdala lesions do not exhibit freezing or analgesia in the presence of a cat (Blanchard \& Blanchard 1972, Fox \& Sorenson 1994), they show attenuated unconditional analgesia and heart rate responses to loud noises (Bellgowan \& Helmstetter 1996, Young \& Leaton 1996), and they exhibit reduced taste neophobia (Nachman \& Ashe 1974). Amygdala damage does not disrupt all unconditional fear responses, however. Amygdala lesions do not affect either open arm avoidance in an elevated plus maze (Treit \& Menard 1997, Treit et al 1993) or unconditional analgesia to shock (Watkins et al 1993). Nonetheless, the impact of amygdala lesions on unconditional fear raises questions regarding the nature of the deficits observed in associative tasks (Cahill et al 1999, Vazdarjanova 2000). It has been argued that deficits in conditional freezing in rats with neurotoxic BLA lesions, for example, may represent a deficit in performing the freezing response, as opposed to a deficit in learning and memory per se (Vazdarjanova \& McGaugh 1998).

We have addressed this issue by submitting rats to an extensive overtraining procedure in which they receive more than 10 times the number of footshocks needed to produce asymptotic levels of freezing in controls (Maren 1998, 1999b). Under these conditions, rats with BLA lesions acquire the conditional freezing response and perform the response at the same high level as control subjects. It is noteworthy that the same overtraining procedure does not eliminate the severe deficits that are induced by posttraining BLA lesions, nor does it facilitate reacquisition of conditional fear during subsequent training (i.e. overtraining does not promote savings of the fear memory) relative to a naive group of animals (see Figure 3). These and other data reveal that fear conditioning deficits in rats with BLA lesions are not simply due to performance deficits. In contrast, they imply a role for the BLA in associative processes underlying fear conditioning (Maren 2000). 


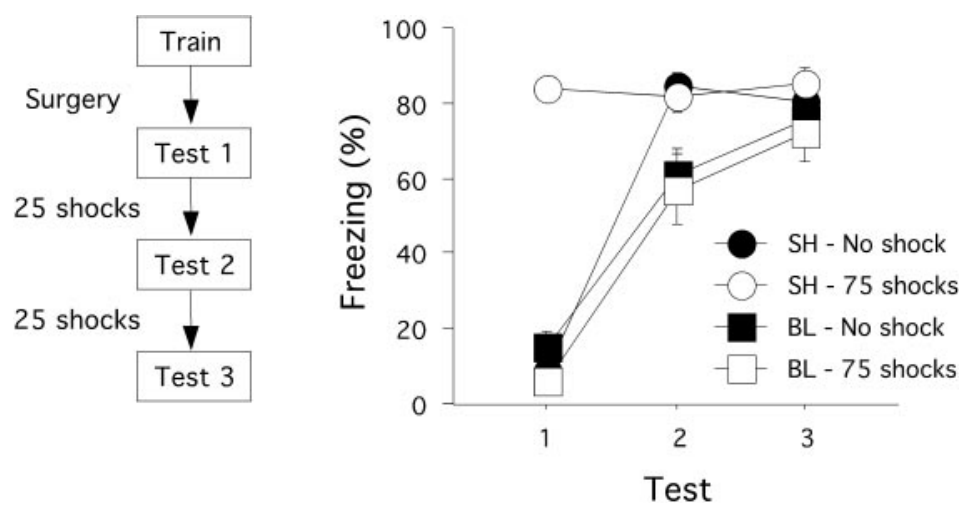

Figure 3 Overtraining does not mitigate the effects of posttraining basolateral amygdala (BLA) lesions. The left panel illustrates the phases of behavioral training and testing. All rats received fear conditioning, consisting of either 0 or 75 unsignaled footshocks in a novel chamber. For each training condition, the rats were further divided into those that received posttraining BLA lesions (BL-no shock, BL-75 shocks) or sham surgery (SH-no shock, SH-75 shocks). All rats then received three 4-min extinction tests, with 25 additional trials following both the first and second test. The right panel illustrates the mean $( \pm)$ SEM percentage of freezing in these groups of rats. Posttraining BLA lesions completely eliminated conditional freezing measured during Test 1, despite presurgical overtraining. However, rats with BLA lesions were able to acquire conditional fear with additional training. BLA rats with presurgical overtraining (BL-75 shocks) acquired conditional freezing at the same rate as conditioning-naive BLA rats (BL-no shock). Overtraining did not yield savings of the fear memory in rats with BLA lesions. (Adapted from Maren 1999b.)

One experimental strategy that oversteps the problems associated with permanent brain lesions employs pharmacological agents to temporarily inactivate brain regions. This technique has now yielded important information concerning the role of the amygdala in the acquisition and expression of conditional fear. For example, inactivation of BLA neurons with muscimol, a $\mathrm{GABA}_{\mathrm{A}}$ receptor agonist, prevents both the acquisition and expression of fear conditioning (Helmstetter \& Bellgowan 1994, Muller et al 1997, Wilensky et al 1999). In addition, muscimol only blocks conditioning when it is infused prior to training-immediate posttraining infusions of muscimol do not affect the acquisition of fear conditioning (Wilensky et al 1999). A similar outcome is obtained with intra-amygdaloid infusions of the $N$-methyl-D-aspartate (NMDA) receptor antagonist, APV (Maren et al 1996b). APV blocks the acquisition of conditional freezing when infused into the BLA before, but not immediately after, training. These results suggest that activity in BLA neurons is required when CS-US association occurs. Posttraining inactivation of the amygdala with either lidocaine or tetrodotoxin, which inhibits both cellular and axonal excitability, does in fact impair fear conditioning (Sacchetti et al 1999, Vazdarjanova \& McGaugh 1999). This may indicate a role for amygdala neurons in consolidating fear memories (see below), although the 
effects of these drugs on en passant axons may be responsible for the observed deficits.

Fear Conditioning-Related Spike Firing in the Amygdala Electrophysiological recordings of amygdaloid neuronal activity support a role for the amygdala in encoding and storing fear associations. In a series of elegant single-unit recording studies, LeDoux and colleagues have discovered that auditory fear conditioning induces short-latency plasticity in LA neurons (Quirk et al 1995, 1997). This plasticity takes the form of enhanced spike firing elicited by acoustic CSs. The short latency of learning-related changes in spike firing is consistent with plasticity in thalamo-amygdala projections, specifically, projections from the medial division of the medial geniculate nucleus (MGm). Amygdala neurons exhibit plasticity earlier in training than auditory cortical neurons, further suggesting that direct thalamoamygdala projections, rather than cortico-amygdala projections, mediate neuronal plasticity in the LA (Quirk et al 1997). As shown in Figure 4, we have recently demonstrated that conditioning-related increases in CS-elicited spike firing in LA neurons are also evident in overtrained rats (Maren 2000). Again, the latency of peak conditional activity is consistent with plasticity in thalamo-amygdala projections. It is noteworthy that the amygdala is not essential for short-latency plasticity in the auditory cortex (Armony et al 1998), although the behavioral relevance of cortical plasticity in rats with amygdala damage is unclear.

In addition to enhancing CS-elicited spike firing in the amygdala, fear conditioning also increases anticipatory, pre-CS firing (Pare \& Collins 2000). Lateral
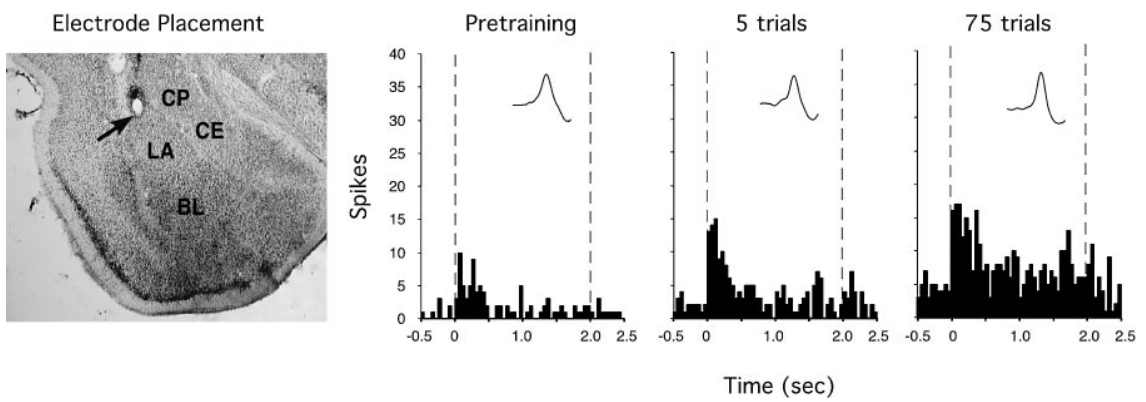

Figure 4 Conditioning-related plasticity in lateral amygdala neurons after overtraining. (Leftmost panel) Electrode placement in the dorsal division of the lateral amygdaloid nucleus. Spike firing rate from a single LAd neuron (inset, spike waveform) during three phases of training is shown in the three unit histograms. The histograms display the summed spike activity obtained during 10 auditory continual stimulus (CS) presentations (50-ms bins). Auditory CSs elicited spike firing in lateral amygdala neurons prior to fear conditioning (pretraining) 50-100 ms following CS onset (dashed lines, CS onset and offset). After five conditioning trials, significant increases in CS-elicited spike firing were observed in several post-CS bins, most notably the short-latency ( $0-50 \mathrm{~ms}$ ) bin. Extensive overtraining (75 trials) did not mitigate the enhancement in short-latency, CS-elicited spike firing. (Adapted from Maren 2001a.) 
amygdala neurons have also been found to exhibit discriminative plasticity in a differential fear-conditioning paradigm in cats (Collins \& Pare 2000). In this case, LA neurons actually show decreases in spike firing elicited by the CS- over the course of training. The cellular mechanism for increases in firing to the $\mathrm{CS}+$ on the one hand and decreases in firing to the $\mathrm{CS}-$ on the other are not known but may involve synaptic plasticity mechanisms such as long-term potentiation (LTP) and long-term depression (LTD) (Maren 1999a).

The critical role for the amygdala in both the acquisition and expression of Pavlovian fear conditioning implies that conditioning-related plasticity in amygdala neurons is due to local synaptic plasticity rather than passive transmission of plasticity from afferent brain areas. In the case of auditory fear conditioning, however, cellular plasticity develops in both the thalamic medial geniculate nucleus (medial division, MGm), which is the primary auditory afferent of the amygdala (Edeline \& Weinberger 1992, McEchron et al 1995, Supple \& Kapp 1989), and the auditory cortex (Weinberger 1995) after auditory fear conditioning. The latency of CS-elicited plasticity in LA is not consistent with transmission of plasticity from the cortex (Maren 2001a, Quirk et al 1997). However, transmission of plasticity from the MGm cannot be ruled out (Cahill et al 1999, Weinberger 1993). Indeed, MGm neurons are capable of LTP (Gerren \& Weinberger 1983), and synaptic plasticity has been demonstrated to occur in the MGm during fear conditioning (McEchron et al 1996). Therefore, further studies are required to determine whether learning-induced changes in amygdala spike firing arise from local or remote synaptic plasticity.

Is the Amygdala Only Involved in Pavlovian Association Formation? The role of the amygdala in aversive conditioning is not limited to encoding and storing Pavlovian CS-US associations. There is substantial evidence that the amygdala is involved in consolidating memories for aversive experiences outside of the amygdaloid circuitry (Cahill \& McGaugh 1998, McGaugh 2000). Amygdaloid involvement in memory consolidation is particularly robust for fear-motivated instrumental learning tasks (Liang et al 1982, Tomaz et al 1991), and the BL, in particular, has an important role in instrumental avoidance learning (Amorapanth et al 2000, Killcross et al 1997, Maren et al 1991, Poremba \& Gabriel 1999). The role for the amygdala in Pavlovian association formation and memory consolidation is dissociable. For example, posttraining inactivation of the amygdala with muscimol produces deficits in the retention of inhibitory avoidance conditioning but not Pavlovian fear conditioning (Wilensky et al 2000). Therefore, the nature of the amygdala's involvement in aversive learning, whether it be local memory storage or remote memory consolidation, depends importantly on the associative structure of the conditioning situation (Kapp et al 1978).

Of course, it is also important to stress that the amygdala does not encode every aspect of an aversive learning experience. For example, humans with amygdala damage exhibit intact declarative memory for a fear conditioning experience, despite failing to exhibit conditional fear responses to stimuli paired with loud noise 
(Bechara et al 1995). Similarly, rats with amygdala lesions avoid a compartment in which they have received footshock, despite failing to exhibit conditional freezing to the contextual cues associated with shock (Vazdarjanova \& McGaugh 1998). These results indicate that multiple memory systems are engaged during relatively simple learning and memory tasks.

\section{Context Processing and the Hippocampus}

In a typical fear conditioning experiment rats acquire fear to not only the CS paired with the US, but also to the contextual cues associated with US delivery. As mentioned above, fear conditioning to both contextual and discrete CSs requires neurons in the amygdala. However, the neural pathways involved in processing these types of stimuli before they come into association with shock are quite different. Whereas information regarding discrete CSs appears to reach the amygdala via direct projections from primary sensory areas in both the thalamus and the cortex, information concerning contextual CSs is transmitted to the amygdala via multisensory brain areas. In fact, recent work has elucidated neural circuitry in the hippocampal formation that is responsible for assembling contextual representations and transmitting these representations to the amygdala for association with USs.

Contextual Encoding The first clues to the neural pathways involved in contextual fear conditioning came from a series of studies indicating that electrolytic lesions of the dorsal hippocampus $(\mathrm{DH})$ prevented both the acquisition and expression of contextual fear conditioning (Kim \& Fanselow 1992, Phillips \& LeDoux 1992, Selden et al 1991). The impairment of contextual fear conditioning exhibits a temporal dependence typical of that found in human amnesia (Squire \& Zola Morgan 1991). Hippocampal lesions only impaired the memory for contextual fear conditioning when made within one month of training (Kim \& Fanselow 1992). This pattern of results has now been demonstrated using an elegant within-subjects design (Anagnostaras et al 1999a) and neurotoxic hippocampal lesions (Maren et al 1997). DH lesions tend to spare fear conditioning to auditory CSs (Anagnostaras et al 1999a; Kim \& Fanselow 1992; Phillips \& LeDoux 1992, 1994), although larger neurotoxic lesions that include the subiculum appear to produce deficits in auditory fear conditioning in many cases (Maren 1999c, Maren et al 1997, Richmond et al 1999). Nonetheless, there is considerable evidence that indicates that contextual and auditory fear conditioning are mediated, at least in part, by dissociable neural systems (Pugh et al 1997, Rudy 1993, Rudy et al 1999).

The fact that auditory conditioning is largely spared in rats with DH damage suggests that the DH does not play a direct role in CS-US association per se. What is the role, then, of the hippocampus in processing contextual information? One possibility is that the hippocampus is involved in mediating context-US associations. There is some evidence for this possibility (Frohardt et al 2000, Wilson et al 1995). However, there are many cases in which context-US associations are 


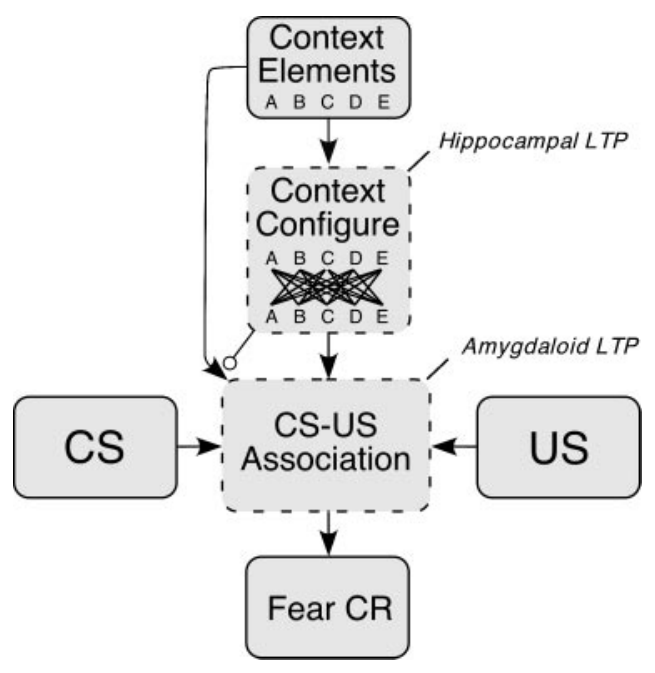

Figure 5 A model illustrating the roles for hippocampal and amygdaloid long-term potentiation (LTP) in Pavlovian fear conditioning. Contextual stimuli (elements) are assembled into configural representations in the hippocampus, and hippocampal LTP is posited as a mechanism underlying this process. Elemental or configural representations of context can come into association with footshock in the amygdala, although configural representations do so at the expense of elemental representations in intact animals (indicated by the inhibitory link, open circle). Discrete conditional stimuli (CS) and unconditional stimuli (US) converge upon amygdala neurons, and amygdaloid LTP is posited to play a role in CS-US association formation.

formed in animals with hippocampal damage (see below). Another possibility is that the hippocampus is required for assembling the elemental cues within a particular training context into a configural representation (Fanselow 1990) that then comes into association with footshock in the amygdala (see Figure 5). Support for this view comes from the finding that hippocampal lesion-induced deficits in contextual fear conditioning can be eliminated if preexposure to the context occurs one month prior to conditioning (Young et al 1994). Presumably, contextual conditioning (and the formation of a context-US association) proceeds normally in this case because the contextual representation was encoded and consolidated prior to the hippocampal damage.

Although initial reports found that electrolytic DH lesions produced impairments of contextual fear conditioning (Kim et al 1993a; Maren \& Fanselow 1997; Phillips \& LeDoux 1992, 1994), more recent reports indicate that axon-sparing neurotoxic lesions of the DH do not yield contextual conditioning deficits when made prior to training (Cho et al 1999, Frankland et al 1998, Gisquet-Verrier et al 1999, Maren et al 1997). However, posttraining neurotoxic DH lesions produce massive deficits in contextual fear conditioning (Maren et al 1997). The differential 
effects of pre- and posttraining neurotoxic DH lesions suggest the existence of alternate strategies for acquiring contextual fear (Maren et al 1997, 1998). We have proposed that intact rats use a hippocampal-dependent configural strategy in which a unified representation of the situational cues associated with training is assembled and associated with footshock. Indeed, recent work by Rudy and colleagues indicates that intact rats do use a configural strategy to acquire contextual fear conditioning (Rudy \& O'Reilly 1999). Once acquired in this manner, the contextual fear memory is sensitive to posttraining hippocampal lesions. In contrast, rats with pretraining hippocampal lesions do not use a configural strategy and they default to a hippocampus-independent elemental strategy in which individual cues in the context come into association with footshock. Both strategies can be used to successfully acquire contextual fear, although only the configural strategy requires hippocampal involvement and it is presumed to operate at the expense of the elemental strategy in intact rats (Figure 5) (Anagnostaras et al 2001, Fanselow 2000, Maren et al 1997, 1998).

Why then do rats with pretraining electrolytic DH lesions have impairments in the acquisition of contextual fear conditioning? Deficits in the acquisition of contextual fear conditioning in rats with electrolytic DH lesions appear to be the result of a disruption of connections between the ventral subiculum and the nucleus accumbens. We have found that electrolytic or neurotoxic lesions of the ventral subiculum, a major afferent of the nucleus accumbens, produce contextual fear conditioning deficits (Maren 1999c). Lesions of the fornix, the tract through which subiculo-accumbens fibers travel, also impair contextual fear conditioning (Maren \& Fanselow 1997, Phillips \& LeDoux 1995). Moreover, Westbrook and colleagues have found that pharmacological inactivation of the accumbens produces selective deficits in the acquisition of contextual fear conditioning (Haralambous \& Westbrook 1999, Westbrook et al 1997; see also Riedel et al 1997). Disruption of subiculo-accumbens projections appears to disregulate exploratory behavior and may interfere with the process by which rats sample contextual cues in their environment (Fanselow 2000, Maren 1999c).

Needless to say, the pattern of deficits following damage to the hippocampal system is complicated. Some have argued for a more parsimonious account of these data that centers around the influence of hippocampal damage on the performance of behavioral responses commonly used to assess fear, such as freezing (Gewirtz et al 2000). For example, Davis and colleagues have found that hippocampal lesions do not affect either contextual fear conditioning (McNish et al 1997) or contextual blocking (McNish et al 2000) assessed by measuring fear-potentiated startle. To account for this pattern of results, they and others have argued that deficits in contextual conditioning are due to a disruption of freezing behavior by the locomotor hyperactivity that typically accompanies hippocampal damage (Gewirtz et al 2000, Good \& Honey 1997). However, it is clear that freezingperformance deficits are not sufficient to account for the full range of deficits associated with hippocampal damage (Anagnostaras et al 2001, Maren et al 1998). For example, rats with DH lesions exhibit a robust impairment for freezing when 
tested in a context in which they received shock 1 day before the lesion, but exhibit normal and high levels of freezing when tested in a context in which they received shock 50 days before the lesion (Anagnostaras et al 1999a). Because the same rats are freezing at high levels in one context and at low levels in another context, one cannot explain their deficits in expression of the recent memory in terms of a freezing-performance problem. Although hippocampal damage surely interacts with freezing behavior, there is strong evidence that such damage is also characterized by associative deficits in contextual fear conditioning.

Contextual Memory Retrieval In addition to its role in encoding contextual representations, we have recently discovered an important role for the hippocampus in the regulation of memory retrieval by context (Holt \& Maren 1999, Maren \& Holt 2000). In many Pavlovian conditioning paradigms a CS can acquire more than one meaning. For example, in latent inhibition a phase of CS-alone presentations (CS preexposure) precedes the conditioning phase, in which the CS is paired with the US. In this paradigm the CS comes to have two meanings: It first comes to predict nothing (e.g. CS-no event) and subsequently comes to predict the US (e.g. CS-shock). Latent inhibition is characterized by a reduction in conditional responding to the $\mathrm{CS}$ that is produced by interference between these two conflicting memories (Bouton 1993). Contextual cues can be used to disambiguate these competing memories. Hence, if preexposure and conditioning occur in different contexts, latent inhibition is greatly reduced. Moreover, if an animal is returned to the preexposure context after the training phase latent inhibition is renewed. That is, conditional responding to the CS is once again reduced if testing occurs in the context of preexposure. It is apparent that animals can use contextual cues to retrieve the meaning of the CS appropriate to that context.

Early theories of hippocampal function posited a role for the hippocampus in this type of contextual memory retrieval (Hirsh 1974). However, recent investigations of retrieval phenomena using permanent hippocampal lesions have yielded mixed results (Frohardt et al 2000, Honey \& Good 1993, Wilson et al 1995). To further investigate the role of the hippocampus in memory retrieval, we used muscimol to reversibly inactivate hippocampal neurons during a latent inhibition retrieval test (Holt \& Maren 1999). The use of a reversible lesion technique for these experiments was critical because it allowed us to selectively target the hippocampus during retrieval testing. As previously reported, we found that control rats exhibited robust contextual retrieval. That is, they showed attenuated conditional responding when exposed to the CS in the context of preexposure and high levels of responding when the CS was tested in a context different from that of preexposure. It is important that hippocampal inactivation eliminated the contextual regulation of conditional responding - rats receiving intrahippocampal muscimol infusions exhibited low levels of conditional responding in both test contexts. They were unable to use contextual cues to regulate performance of the different CS memories and in fact, performed purely according to the sum of their experiences with the CS. Because they had 30 times as many CS-no event trials as CS-US trials, they performed 
according to the former association and exhibited little conditional responding (Maren \& Holt 2000). A similar role for the hippocampus in contextual retrieval has been demonstrated in studies of human memory (Chun \& Phelps 1999). Together, these studies are beginning to open up a new realm of hippocampal function in the processing of contextual cues, conditional relations, and high-order learning phenomenon such as occasion setting (Holland \& Bouton 1999, Honey \& Good 2000).

\section{Fear Inhibition and the Prefrontal Cortex}

In addition to understanding the processes by which fear memories are established and expressed, there is considerable interest in the mechanisms by which fear memories are inhibited. Understanding fear reduction has important clinical implications for treating disorders of fear and anxiety, such as posttraumatic stress disorder and panic disorder. There is considerable evidence implicating the prefrontal cortex (PFC) in emotional processes (Davidson \& Irwin 1999), and there is an emerging, but complicated, literature suggesting a role for the PFC in the inhibition of conditional fear. For example, PFC lesions have been reported to attenuate extinction of fear under some conditions (Morgan \& LeDoux 1995, Morgan et al 1993). However, others have not found an effect of PFC lesions on extinction (Gewirtz et al 1997). Recently, Quirk and colleagues reported that PFC lesions do not affect the acquisition or extinction of conditional fear per se, but either impair consolidation or affect the contextual modulation of the extinction memory (Quirk et al 2000).

One paradigm that has been adopted to study fear reduction is conditioned inhibition. A number of brain structures known to be important for excitatory fear conditioning, including the amygdala, perirhinal cortex, and medial geniculate nucleus, do not appear to be involved in conditioned inhibition of fear (Falls et al 1997, Falls \& Davis 1995, Heldt \& Falls 1998). Moreover, the PFC does not appear to be required for conditioned inhibition (Gewirtz et al 1997, Vouimba et al 2000), although recordings of prefrontal cortical activity reveal that there is an amygdaladependent reduction of spike firing to a conditioned inhibitor (Garcia et al 1999). Thus, the neural substrates underlying the inhibition of fear remain elusive.

\section{SYNAPTIC AND MOLECULAR MECHANISMS OF FEAR CONDITIONING}

Considerable progress in mapping the neural circuitry underlying fear conditioning has opened the door to analyses of the synaptic and molecular mechanisms underlying the formation and storage of fear memories. In general, the focus of these studies has been to describe the properties of synaptic plasticity in the amygdala and hippocampus, to examine whether fear conditioning is accompanied by synaptic plasticity in these brain structures, and to investigate the influence on fear conditioning of manipulations that perturb synaptic plasticity in fear conditioning 
circuits. The evidence supports the view that synaptic plasticity in the amygdala is involved in CS-US association, whereas synaptic plasticity in the hippocampus is involved in contextual encoding.

Long-term potentiation (LTP) is the prototypical form of enduring synaptic plasticity in the mammalian brain (Bliss \& Collingridge 1993, Maren \& Baudry 1995, Martin et al 2000). It was first discovered in the hippocampus (Bliss \& Lomo 1973), and has now been demonstrated to occur at synapses in the amygdala (Chapman et al 1990, Clugnet \& LeDoux 1990, Maren \& Fanselow 1995). Several properties of LTP, such as its rapid induction and associativity, make it an ideal candidate for encoding Pavlovian fear memories (Fanselow 1993, Maren 1999a, Rogan \& LeDoux 1996). Although there is considerable debate concerning the role of LTP in learning and memory (Izquierdo \& Medina 1995, Martin et al 2000, Shors \& Matzel 1997), we have argued that Pavlovian fear conditioning is the ideal model system for examining the LTP-learning connection (Maren 2001b).

\section{Glutamate Receptors and Fear Conditioning}

The first series of studies to implicate LTP in Pavlovian fear conditioning used antagonists of the NMDA subclass of glutamate receptors. NMDA receptors are required for the induction of some forms of LTP in both the hippocampus (Bliss \& Collingridge 1993, Maren \& Baudry 1995) and the amygdala (Huang \& Kandel 1998, Maren \& Fanselow 1995). In a groundbreaking study, Davis and colleagues demonstrated that infusion of the NMDA receptor antagonist, APV, into the BLA prevents the acquisition of conditional fear to a visual CS in a fear-potentiated startle paradigm (Miserendino et al 1990). The attenuation of fear conditioning by APV was dose-dependent and was not due to an APV-induced decrease in footshock sensitivity. It is important to note that APV infusion into the BLA before testing did not affect the performance of a fear conditional response acquired in an earlier phase of training. Furthermore, APV infusion into the cerebellar interpositus nucleus, a brain structure that is not required for fear conditioning, did not affect acquisition of fear-potentiated startle. Subsequent work demonstrated that intra-amygdala APV also blocks the acquisition, but not the expression, of fear-potentiated startle to acoustic CSs (Campeau et al 1992). The deleterious effect of APV on fear-potentiated startle acquisition has also been demonstrated for second-order conditioning, suggesting that APV impairs fear conditioning by attenuating an associative mechanism, rather than affecting CS or US processing per se (Gewirtz \& Davis 1997).

The effects of intra-amygdala APV have also been examined in the conditionalfreezing paradigm (Maren et al 1996b). We have reported that infusions of APV into the BLA before fear conditioning produce a robust impairment in the acquisition of conditional freezing measured either immediately after footshock or 24 hours following conditioning. APV only blocked conditioning when it was infused into the BLA before training; immediate posttraining infusions of APV did not affect the acquisition of conditional freezing (Maren et al 1996b). However, unlike the 
results obtained from the fear-potentiated startle paradigm, we found that the effects of APV were not specific to acquisition; the expression of a previously acquired fear conditional response was also impaired by APV (Maren et al 1996b). This pattern of results has recently been replicated (Lee \& Kim 1998) and may be due to the influence of NMDA receptor antagonists on evoked potentials in the amygdala (Li et al 1995, Maren \& Fanselow 1995). Thus, it appears that amygdaloid NMDA receptor activation has a general role in the acquisition of fear CRs and a selective role in the expression of the conditional freezing (see Lee \& Kim 1998 for a discussion of this issue). Intracerebroventricular administration of APV (Fanselow et al 1994; Kim et al 1991, 1992) and intrahippocampal APV infusions (Young et al 1994) indicate that hippocampal NMDA receptors appear to have a more selective role in contextual fear conditioning.

Recent work indicates that, as in the hippocampus (Grover \& Teyler 1990), there are forms of amygdaloid LTP that do not depend on NMDA receptor activation (Chapman \& Bellavance 1992, Weisskopf et al 1999) but do require the activation of voltage-gated calcium channels (Weisskopf et al 1999). Calcium channel-dependent plasticity may play an important role in fear conditioning, although this possibility has yet to be explored. Similarly, non-NMDA (i.e. AMPA) receptors also play an important role in fear conditioning. For example, Davis and colleagues have shown that intra-amygdala infusion of AMPA receptor antagonists impair both the acquisition and expression of fear-potentiated startle (Kim et al 1993b, Walker \& Davis 1997). Additionally, LeDoux and colleagues have shown that AMPA receptor agonists infused into the amygdala prior to training enhance the acquisition of conditional freezing (Rogan et al 1997a). Recent studies also suggest that both cholinergic (Anagnostaras et al 1999b, Rudy 1996) and dopaminergic (Guarraci et al 1999, Nader \& LeDoux 1999) neurotransmission play a role in the acquisition and expression of conditional fear. It is therefore likely that several interacting neurochemical systems regulate the synaptic plasticity in the amygdala that is critical for fear conditioning.

\section{Synaptic Plasticity in Fear Conditioning Circuits}

The foregoing studies indicate that both hippocampal and amygdaloid NMDA receptors are involved in the acquisition of Pavlovian fear conditioning in rats. These results implicate NMDA receptor-dependent LTP in these brain areas in the acquisition of conditional fear. A number of studies have used a correlational approach to examine the role of hippocampal LTP in contextual fear conditioning. Moreover, several studies have directly assessed amygdaloid synaptic transmission during, or shortly after, fear conditioning. These studies suggest that hippocampal LTP is involved in encoding contextual representations, whereas amygdaloid LTP is involved in the formation and storage of CS-US associations (Figure 5).

Correlations Between Hippocampal LTP and Contextual Fear Conditioning To explore the relationship between hippocampal LTP and Pavlovian fear conditioning, we examined the influence of behavioral manipulations that enhance 
learning rate on both the induction of hippocampal LTP and the acquisition of contextual fear conditioning. We submitted rats to acute water deprivation and found that deprivation reliably enhanced the magnitude of hippocampal LTP induced by high-frequency stimulation and augmented the rate of contextual fear conditioning; deprivation did not augment auditory fear conditioning (Maren et al 1994a,b; Maren \& Fanselow 1998). Similar correlations between hippocampal LTP induction and contextual fear conditioning have emerged from studies of sex differences in LTP and fear conditioning (Anagnostaras et al 1998, Maren et al 1994c). Moreover, synaptic plasticity in hippocampo-septal projections has also been found to play a role in contextual fear conditioning (Garcia \& Jaffard 1992, Vouimba et al 1998). These correlations are consistent with hypotheses that invoke hippocampal LTP as a mechanism for contextual fear conditioning (Fanselow 1997, Maren 1997). More specifically, these results suggest that hippocampal LTP has an important role in processing contextual CSs and may be involved in establishing configural representations of contextual stimuli (Maren 2001b).

Fear Conditioning Induces LTP in the Amygdala As indicated above, the blockade of fear conditioning by NMDA receptor antagonists in the amygdala suggests that amygdaloid LTP mediates fear conditioning (Maren 1999a). This possibility has received support from a series of experiments performed by LeDoux and colleagues. Rogan \& LeDoux (1995) found that induction of LTP at thalamoamygdaloid synapses in vivo potentiates auditory evoked potentials in the amygdala that use this pathway. Auditory evoked potentials in the thalamo-amygdaloid pathway were also augmented during the acquisition of auditory fear conditioning (Rogan et al 1997b). The similar increase in auditory evoked potentials in the amygdala following both tetanic LTP induction and fear conditioning suggests that LTP-like increases in thalamo-amygdaloid synaptic transmission contribute to the acquisition of auditory fear conditioning.

McKernan \& Shinnick-Gallagher (1997) have shown that fear conditioning enhances the amplitude of synaptic currents in amygdaloid neurons in vitro. Rats receiving paired CS-US trials, but not those receiving unpaired trials, exhibited a marked increase in synaptic currents evoked in amygdaloid neurons by stimulation of thalamic afferents. This increase in synaptic transmission was due to an elevation of presynaptic neurotransmitter release. Synaptic transmission in the endopyriform nucleus, which is not believed to play a role in fear conditioning, was not altered by the conditioning procedures. Insofar as tetanus-induced amygdaloid LTP is associated with both increased evoked responses and enhanced neurotransmitter release (Huang \& Kandel 1998, Maren \& Fanselow 1995), it would appear that fear conditioning induces a form of "behavioral" LTP. Further studies are required to determine whether these forms of plasticity share common cellular mechanisms.

Long-Term Depression In addition to LTP, both the amygdala and hippocampus exhibit use-dependent decreases in synaptic efficacy under some conditions (Bramham \& Srebro 1987, Heinbockel \& Pape 2000, Li et al 1998, Wang \& Gean 
1999). The precise role for long-term depression (LTD) in fear conditioning is not known, although one can certainly imagine the necessity for bidirectional synaptic plasticity in fear conditioning circuits. In the amygdala LTD may be responsible for limiting synaptic transmission in CS pathways that are uncorrelated or anticorrelated with US occurrence. For example, amygdala neurons decrease their firing to a CS that is not explicitly paired with a US (Collins \& Pare 2000). In general, amygdaloid LTD may be a mechanism whereby stimuli acquire inhibitory properties, which is consistent with a role for the amygdala in some forms of inhibitory learning, such as extinction (Falls et al 1992).

\section{Molecular Cascades for Fear Memories}

The elaboration of LTP as a mechanism for fear conditioning has been fostered not only by pharmacological and electrophysiological experiments but also by a new breed of experimentation that is driven by our expanding knowledge of intracellular signal transduction pathways and the molecular genetics of these pathways. These studies have taken two approaches. The first is a standard pharmacological approach, in which various components of the signal transduction cascade associated with LTP, for example, are targeted with drugs in behaving animals. The second approach takes advantage of powerful new molecular techniques to disable, eliminate, or even enhance key proteins associated with synaptic plasticity.

Protein Kinase Inhibitors It is well documented that NMDA receptor activation is only the first step in a biochemical cascade that ultimately leads to synaptic modification. Activation of intracellular protein kinases, which are stimulated by NMDA receptor activation, is essential for the induction of LTP in both the hippocampus and amygdala (Huang \& Kandel 1998, Huang et al 2000). Examinations of the role for protein kinases in fear conditioning are in their infancy, but there is already evidence that various kinases are required for establishing long-term fear memories. For instance, Kandel and colleagues have shown that posttraining intracerebroventricular (ICV) administration of protein kinase A (PKA) inhibitors impairs memory consolidation for contextual fear conditioning (Bourtchouladze et al 1998). Likewise, LeDoux and colleagues have found that posttraining ICV administration of PKA and mitogen-activated protein kinase (MAPK) inhibitors disrupts memory for contextual and auditory fear conditioning (Schafe et al 1999).

We have recently examined the influence of intra-amygdala infusions of $\mathrm{H} 7$, an inhibitor of protein kinase $\mathrm{C}$ (PKC) and PKA. This procedure allowed us to address the question of whether the attenuation of fear conditioning observed after ICV administration of kinase inhibitors was due to an effect on amygdaloid kinase activity. Consistent with the ICV data, we found that intra-amygdala infusions of $\mathrm{H} 7$ selectively inhibited the formation of long-term fear memories (Figure 6B)—short-term fear memories were spared (Figure 6A). Moreover, we found that $\mathrm{H} 7$ only affected long-term memory formation when infused into the BLA; CE infusion of $\mathrm{H} 7$ did not attenuate fear conditioning (Figure $6 C$ ). The 

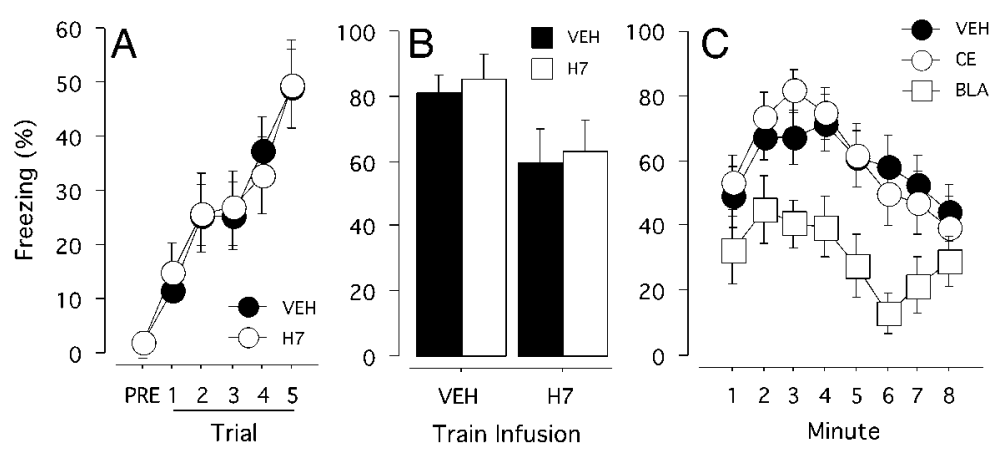

Figure 6 Intra-amygdala infusion of the protein kinase inhibitor $\mathrm{H} 7$ into the basolateral amygdala (BLA) selectively attenuates the acquisition of long-term, but not short-term, conditional fear memories. All panels display mean $( \pm$ SEM) percentage of freezing. $(A)$ Immediate postshock freezing during the conditioning session is not affected by intra-BLA infusions of H7. (B) Contextual freezing expressed 24 hours after fear conditioning is attenuated by pretraining, but not pretesting, (VEH, dark bar; H7, open bar) infusions of H7. This effect was not state dependent. $(C)$ Infusions of $\mathrm{H7}$ into the central nucleus (CE) did not affect the acquisition of contextual freezing. (Adapted from Goosens et al 2000.)

effect of $\mathrm{H} 7$ in the BLA on fear conditioning was not modality specific insofar as both auditory and contextual fear memories were attenuated. Also, it should be noted that $\mathrm{H} 7$ did not affect the expression of already learned fear memories (Figure $6 B$ ). These data suggest that protein kinase activation in the BLA is required for consolidating long-term fear memories. Ultimately, the consolidation (and reconsolidation) of fear memories requires de novo protein synthesis, insofar as intra-amygdala infusions of protein synthesis inhibitors, such as anisomycin (Nader et al 2000), and mRNA synthesis inhibitors, such as actinomycin-D (Bailey et al 1999), impair long-term memory formation. The induction of immediate early genes, such as $c$-fos and zif 268 , in the amygdala after fear conditioning may be a key component of the molecular cascade that leads to protein synthesis-dependent memory consolidation (Beck \& Fibiger 1995, Campeau et al 1991, Malkani \& Rosen 2000, Rosen et al 1998).

Genetically Modified Mice As indicated above, it is clear that the NMDA receptor plays an important role in Pavlovian fear conditioning. Recently, transgenic techniques have been used to manipulate NMDA receptors in the hippocampus (Tsien et al 1996). Elimination of key NMDA receptor subunits in mice has been found to attenuate the acquisition of contextual fear conditioning (Kiyama et al 1998). Recent work indicates that trace fear conditioning, which is dependent on the hippocampus (McEchron et al 1998), is also impaired in mice that lack hippocampal NMDA receptors (Huerta et al 2000). Contextual fear conditioning deficits in hippocampal NMDA receptor-knockout mice are overcome by 
environmental enrichment (Rampon et al 2000). Perhaps one of the more interesting results to emerge in recent years is the finding that mice that overexpress the NMDA receptor $2 \mathrm{~B}$ subunit, which prolongs the activation of NMDA receptors, actually exhibit enhanced hippocampal LTP and contextual fear conditioning (Tang et al 1999). Collectively, these data confirm pharmacological data that indicate an important role for NMDA receptors in synaptic plasticity and fear conditioning. Unfortunately, amygdala-specific NMDA receptor knockouts have not been developed. However, as discussed above, pharmacological and electrophysiological data clearly support a role for amygdaloid NMDA receptors and LTP in Pavlovian fear conditioning.

Studies using genetically modified mice also implicate various protein kinases that are linked to NMDA receptor activation in both LTP and learning and memory. Mice that lack PKC $\gamma$ exhibit mild deficits in contextual, but not auditory, fear conditioning (Abeliovich et al 1993b). They also exhibit normal immediate postshock freezing, suggesting that only their long-term memory for contextual fear is impaired. The selective deficit in contextual conditioning is interesting insofar as these mice also exhibit impairments in hippocampal LTP (Abeliovich et al 1993a). Mice that lack the $\beta$ isoform of PKC mice exhibit normal hippocampal LTP, but they exhibit robust impairments in both auditory and contextual fear conditioning (Weeber et al 2000). A similar pattern of behavioral results has been observed in mice that either express an inhibitory form of the regulatory subunit for PKA or overexpress $\mathrm{Ca}^{2+}$-calmodulin-dependent protein kinase II , which also play a role in the induction of LTP (Abel et al 1997, Mayford et al 1996). These transgenic mouse strains exhibit long-term, but not short-term, impairments in both contextual and auditory fear conditioning, and both transgenic strains exhibit deficits in hippocampal LTP induction. Unfortunately, amygdaloid LTP was not examined in any of these studies. Deficits in amygdaloid LTP might account for the global fear conditioning impairments in $\mathrm{PKC} \beta$, PKA, and $\mathrm{Ca}^{2+}$-calmodulin-dependent protein kinase II mice. Nonetheless, these findings are consistent with the involvement of protein kinases in both synaptic plasticity and fear conditioning. Indeed, our pharmacological data indicate that PKC and PKA activity in the amygdala is critical for both auditory and contextual fear conditioning (Goosens et al 2000).

Another recent series of studies has examined the influence of a targeted mutation of the cAMP-responsive, element-binding (CREB) protein, which is a transcription factor thought to play an important role in establishing long-term memories, on both fear conditioning and LTP. Mice with a disruption of the $\alpha$ and $\delta$ isoforms of CREB exhibit robust impairments in both contextual and auditory fear conditioning (Bourtchuladze et al 1994). These impairments are time dependent, insofar as freezing to both contexts and tones is intact when measured within 30 or 60 minutes of training, respectively. However, conditional freezing is nearly absent at long ( 24 hour) retention intervals. Thus, CREB mutants are capable of normal freezing under some conditions, and the time-dependent loss of conditional freezing over long retention intervals indicates that CREB is essential for consolidating long-term fear memories. In parallel with the time course of fear conditioning deficits, mice that lacked CREB also exhibited impairments in a late 
phase of hippocampal LTP; short-lasting, posttetanic potentiation is not impaired in these mice (Bourtchuladze et al 1994). The time period over which LTP decayed appears to parallel the time period over which fear memories are lost in CREB mutants. Not all CREB mutants exhibit impaired learning and synaptic plasticity, however. A recent study has found that mice expressing a dominant-negative form of CREB exhibit normal amygdaloid LTP and only minimal fear conditioning deficits in one of three transgenic lines (Rammes et al 2000). Nonetheless, Impey et al (1998) recently reported that both contextual and auditory fear conditioning rapidly induce CREB in the hippocampus and amygdala.

A more direct demonstration of a specific role for amygdaloid LTP in fear conditioning is revealed by studies of mice that lack Ras-GRF, a neuron-specific guanine nucleotide-releasing factor that is activated by both $\mathrm{Ca}^{2+}$ and G-proteincoupled messengers. Electrophysiological recordings from brain slices obtained from mice lacking Ras-GRF indicate a pronounced deficit in the induction of LTP in the BL (Brambilla et al 1997). These mice also exhibit impairments in consolidating long-term fear memories for both contextual and acoustic stimuli. These deficits in LTP and learning are selective for the amygdala and Pavlovian fear conditioning insofar as both hippocampal LTP and spatial learning in RasGRF knockouts are normal (Brambilla et al 1997). Ras-GRF modulates CREB activity through the MAPK pathway, and a role for MAPK in fear conditioning has recently been demonstrated (Atkins et al 1998, Schafe et al 1999). Together, these results provide strong support for the view that synaptic LTP in the amygdala is required for the establishment and maintenance of emotional memories. Further studies are required, however, to more precisely specify the role for amygdaloid and hippocampal synaptic plasticity in Pavlovian fear conditioning.

\section{CONCLUSIONS}

Pavlovian fear conditioning has undergone an extensive neurobiological analysis in recent years. This analysis has revealed that the amygdala and hippocampus are critical components of the neural circuitry underlying association formation and contextual processing, respectively, during fear conditioning. Moreover, synaptic plasticity mechanisms, such as LTP, in the hippocampus and amygdala play distinct and critical roles in these processes (see Figure 5). Most recently, molecular techniques are beginning to unravel the intracellular cascades that underlie the formation and storage of fear memories. Collectively, these advances yield great promise for understanding the neurobiology of learning and memory, in general, and in understanding the neurobiological basis of disorders of fear and anxiety in humans.

\section{ACKNOWLEDGMENTS}

This work was supported by the National Institute of Mental Health (R29MH57865). I thank Ki Goosens for commenting on an earlier draft of the manuscript. 


\section{Visit the Annual Reviews home page at www.AnnualReviews.org}

\section{LITERATURE CITED}

Abel T, Nguyen PV, Barad M, Deuel TA, Kandel ER, et al. 1997. Genetic demonstration of a role for PKA in the late phase of LTP and in hippocampus-based long-term memory. Cell 88:615-26

Abeliovich A, Chen C, Goda Y, Silva AJ, Stevens CF, et al. 1993a. Modified hippocampal long-term potentiation in PKC gammamutant mice. Cell 75:1253-62

Abeliovich A, Paylor R, Chen C, Kim JJ, Wehner JM, et al. 1993b. PKC gamma mutant mice exhibit mild deficits in spatial and contextual learning. Cell 75:1263-71

Adolphs R, Tranel D, Damasio H, Damasio AR. 1995. Fear and the human amygdala. J. Neurosci. 15:5879-91

Adolphs R, Tranel D, Hamann S, Young AW, Calder AJ, et al. 1999. Recognition of facial emotion in nine individuals with bilateral amygdala damage. Neuropsychologia 37:1111-17

Amorapanth P, LeDoux JE, Nader K. 2000. Different lateral amygdala outputs mediate reactions and actions elicited by a fear-arousing stimulus. Nat. Neurosci. 3:74-79

Amorapanth P, Nader K, LeDoux JE. 1999. Lesions of periaqueductal gray dissociateconditioned freezing from conditioned suppression behavior in rats. Learn. Mem. 6:491-99

Anagnostaras SG, Gale GD, Fanselow MS. 2001. The hippocampus and contextual fear conditioning: recent controversies and advances. Hippocampus. In press

Anagnostaras SG, Maren S, DeCola JP, Lane NI, Gale GD, et al. 1998. Testicular hormones do not regulate sexually dimorphic Pavlovian fear conditioning or perforant-path long-term potentiation in adult male rats. Behav. Brain Res. 92:1-9

Anagnostaras SG, Maren S, Fanselow MS. 1999a. Temporally graded retrograde amnesia of contextual fear after hippocampal dam- age in rats: within-subjects examination. $J$. Neurosci. 19:1106-14

Anagnostaras SG, Maren S, Sage JR, Goodrich S, Fanselow MS. 1999b. Scopolamine and Pavlovian fear conditioning in rats: doseeffect analysis. Neuropsychopharmacology 21:731-44

Antoniadis EA, McDonald RJ. 2000. Amygdala, hippocampus and discriminative fear conditioning to context. Behav. Brain Res. 108:1-19

Armony JL, Quirk GJ, LeDoux JE. 1998. Differential effects of amygdala lesions on early and late plastic components of auditory cortex spike trains during fear conditioning. $J$. Neurosci. 18:2592-601

Atkins CM, Selcher JC, Petraitis JJ, Trzaskos JM, Sweatt JD. 1998. The MAPK cascade is required for mammalian associative learning. Nat. Neurosci. 1:602-9

Bailey DJ, Kim JJ, Sun W, Thompson RF, Helmstetter FJ. 1999. Acquisition of fear conditioning in rats requires the synthesis of mRNA in the amygdala. Behav. Neurosci. 113:276-82

Bechara A, Tranel D, Damasio H, Adolphs R, Rockland C, et al. 1995. Double dissociation of conditioning and declarative knowledge relative to the amygdala and hippocampus in humans. Science 269:1115-18

Beck CH, Fibiger HC. 1995. Conditioned fearinduced changes in behavior and in the expression of the immediate early gene c-fos: with and without diazepam pretreatment. $J$. Neurosci. 15:709-20

Bellgowan PS, Helmstetter FJ. 1996. Neural systems for the expression of hypoalgesia during nonassociative fear. Behav. Neurosci. 110:727-36

Blanchard DC, Blanchard RJ. 1972. Innate and conditioned reactions to threat in rats with amygdaloid lesions. J. Comp. Physiol. Psychol. 81:281-90 
Bliss TV, Collingridge GL. 1993. A synaptic model of memory: Long-term potentiation in the hippocampus. Nature 361:31-39

Bliss TV, Lomo T. 1973. Long-lasting potentiation of synaptic transmission in the dentate area of the anaesthetized rabbit following stimulation of the perforant path. J. Physiol. 232:331-56

Bourtchouladze R, Abel T, Berman N, Gordon R, Lapidus K, Kandel ER. 1998. Different training procedures recruit either one or two critical periods for contextual memory consolidation, each of which requires protein synthesis and PKA. Learn. Mem. 5:365-74

Bourtchuladze R, Frenguelli B, Blendy J, Cioffi D, Schutz G, et al. 1994. Deficient long-term memory in mice with a targeted mutation of the cAMP-responsive element-binding protein. Cell 79:59-68

Bouton ME. 1993. Context, time, and memory retrieval in the interference paradigms of Pavlovian learning. Psychol. Bull. 114:80-99

Brady JV, Schreiner L, Geller I, Kling A. 1954. Subcortical mechanisms in emotional behavior: The effect of rhinencephalic injury upon the acquisition and retention of a conditioned avoidance response in cats. J. Comp. Physiol. Psychol. 47:179-86

Brambilla R, Gnesutta N, Minichiello L, White G, Roylance AJ, et al. 1997. A role for the Ras signalling pathway in synaptic transmission and long-term memory. Nature 390:281-86

Bramham CR, Srebro B. 1987. Induction of long-term depression and potentiation by low- and high-frequency stimulation in the dentate area of the anesthetized rat: magnitude, time course and EEG. Brain Res. 405:100-7

Brodal A. 1947. The amygdaloid nucleus in the rat. J. Comp. Neurol. 87:1-16

Brown S, Schäfer A. 1888. An investigation into the functions of the occipital and temporal lobes of the monkey's brain. Philos. Trans. R. Soc. London Ser. B 179:303-27

Buchel C, Dolan RJ, Armony JL, Friston KJ. 1999. Amygdala-hippocampal involvement in human aversive trace condition- ing revealed through event-related functional magnetic resonance imaging. J. Neurosci. 19:10869-76

Cahill L, McGaugh JL. 1998. Mechanisms of emotional arousal and lasting declarative memory. Trends Neurosci. 21:294-99

Chill L, Weinberger NM, Roozendaal B, McGaugh JL. 1999. Is the amygdala a locus of "conditioned fear"? Some questions and caveats. Neuron 23:227-28

Campeau S, Davis M. 1995a. Involvement of subcortical and cortical afferents to the lateral nucleus of the amygdala in fear conditioning measured with fear-potentiated startle in rats trained concurrently with auditory and visual conditioned stimuli. J. Neurosci. 15:231227

Campeau S, Davis M. 1995b. Involvement of the central nucleus and basolateral complex of the amygdala in fear conditioning measured with fear-potentiated startle in rats trained concurrently with auditory and visual conditioned stimuli. J. Neurosci. 15:2301-11

Campeau S, Hayward MD, Hope BT, Rosen JB, Nestler EJ, et al. 1991. Induction of the c-fos proto-oncogene in rat amygdala during unconditioned and conditioned fear. Brain Res. 565:349-52

Campeau S, Miserendino MJ, Davis M. 1992. Intra-amygdala infusion of the N-methylD-aspartate receptor antagonist AP5 blocks acquisition but not expression of fearpotentiated startle to an auditory conditioned stimulus. Behav. Neurosci. 106:569-74

Chapman PF, Bellavance LL. 1992. Induction of long-term potentiation in the basolateral amygdala does not depend on NMDA receptor activation. Synapse 11:310-18

Chapman PF, Kairiss EW, Keenan CL, Brown TH. 1990. Long-term synaptic potentiation in the amygdala. Synapse 6:271-78

Cho YH, Friedman E, Silva AJ. 1999. Ibotenate lesions of the hippocampus impair spatial learning but not contextual fear conditioning in mice. Behav. Brain Res. 98:7787

Chun MM, Phelps EA. 1999. Memory deficits 
for implicit contextual information in amnesic subjects with hippocampal damage. Nat. Neurosci. 2:844-47

Clugnet MC, LeDoux JE. 1990. Synaptic plasticity in fear conditioning circuits: induction of LTP in the lateral nucleus of the amygdala by stimulation of the medial geniculate body. J. Neurosci. 10:2818-24

Collins DR, Pare D. 2000. Differential fear conditioning induces reciprocal changes in the sensory responses of lateral amygdala neurons to the $\mathrm{CS}(+)$ and $\mathrm{CS}(-)$. Learn. Mem. 7:97-103

Cousens G, Otto T. 1998. Both pre- and posttraining excitotoxic lesions of the basolateral amygdala abolish the expression of olfactory and contextual fear conditioning. Behav. Neurosci. 112:1092-103

Davidson RJ, Irwin W. 1999. The functional neuroanatomy of emotion and affective style. Trends Cogn. Sci. 3:11-21

Davis M. 1992. The role of the amygdala in fear and anxiety. Annu. Rev. Neurosci. 15:353-75

De Oca BM, DeCola JP, Maren S, Fanselow MS. 1998. Distinct regions of the periaqueductal gray are involved in the acquisition and expression of defensive responses. J. Neurosci. 18:3426-32

Edeline JM, Weinberger NM. 1992. Associative retuning in the thalamic source of input to the amygdala and auditory cortex: receptive field plasticity in the medial division of the medial geniculate body. Behav. Neurosci. 106:81-105

Falls WA, Bakken KT, Heldt SA. 1997. Lesions of the perirhinal cortex interfere with conditioned excitation but not with conditioned inhibition of fear. Behav. Neurosci. 111:47686

Falls WA, Davis M. 1995. Lesions of the central nucleus of the amygdala block conditioned excitation, but not conditioned inhibition of fear as measured with the fear-potentiated startle effect. Behav. Neurosci. 109:37987

Falls WA, Miserendino MJ, Davis M. 1992. Extinction of fear-potentiated startle: blockade by infusion of an NMDA antagonist into the amygdala. J. Neurosci. 12:854-63

Fanselow MS. 1990. Factors governing onetrial contextual conditioning. Anim. Learn. Behav. 18:264-70

Fanselow MS. 1993. Associations and memories: The role of NMDA receptors and longterm potentiation. Curr. Dir. Psychol. Sci. 2:152-56

Fanselow MS. 1994. Neural organization of the defensive behavior system responsible for fear. Psychon. Bull. Rev. 1:429-38

Fanselow MS. 1997. Without LTP the learning circuit is broken. Behav. Brain Sci. 20:616

Fanselow MS. 2000. Contextual fear, gestalt memories, and the hippocampus. Behav. Brain Res. 110:73-81

Fanselow MS, Kim JJ. 1994. Acquisition of contextual Pavlovian fear conditioning is blocked by application of an NMDA receptor antagonist D,L-2-amino-5-phosphonovaleric acid to the basolateral amygdala. Behav. Neurosci. 108:210-12

Fanselow MS, Kim JJ, Yipp J, De Oca B. 1994. Differential effects of the Nmethyl-D-aspartate antagonist DL-2-amino5-phosphonovalerate on acquisition of fear of auditory and contextual cues. Behav. Neurosci. 108:235-40

Fanselow MS, LeDoux JE. 1999. Why we think plasticity underlying Pavlovian fear conditioning occurs in the basolateral amygdala. Neuron 23:229-32

Fendt M, Fanselow MS. 1999. The neuroanatomical and neurochemical basis of conditioned fear. Neurosci. Biobehav. Rev. 23:743-60

Fonberg E. 1965. Effect of partial destruction of the amygdaloid complex on the emotionaldefensive behaviour of dogs. Bull. Acad. Pol. Sci. Biol. 13:429-32

Fox RJ, Sorenson CA. 1994. Bilateral lesions of the amygdala attenuate analgesia induced by diverse environmental challenges. Brain Res. 648:215-21

Frankland PW, Cestari V, Filipkowski RK, McDonald RJ, Silva AJ. 1998. The dorsal 
hippocampus is essential for context discrimination but not for contextual conditioning. Behav. Neurosci. 112:863-74

Frohardt RJ, Guarraci FA, Bouton ME. 2000. The effects of neurotoxic hippocampal lesions on two effects of context after fear extinction. Behav. Neurosci. 114:227-40

Garcia R, Jaffard R. 1992. The hippocamposeptal projection in mice: long-term potentiation in the lateral septum. NeuroReport 3:193-96

Garcia R, Vouimba RM, Baudry M, Thompson RF. 1999. The amygdala modulates prefrontal cortex activity relative to conditioned fear. Nature 402:294-96

Gerren RA, Weinberger NM. 1983. Long term potentiation in the magnocellular medial geniculate nucleus of the anesthetized cat. Brain Res. 265:138-42

Gewirtz JC, Davis M. 1997. Second-order fear conditioning prevented by blocking NMDA receptors in amygdala. Nature 388:47174

Gewirtz JC, Falls WA, Davis M. 1997. Normal conditioned inhibition and extinction of freezing and fear-potentiated startle following electrolytic lesions of medical prefrontal cortex in rats. Behav. Neurosci. 111:71226

Gewirtz JC, McNish KA, Davis M. 2000. Is the hippocampus necessary for contextual fear conditioning? Behav. Brain Res. 110:8395

Gisquet-Verrier P, Dutrieux G, Richer P, Doyere V. 1999. Effects of lesions to the hippocampus on contextual fear: evidence for a disruption of freezing and avoidance behavior but not context conditioning. Behav. Neurosci. 113:507-22

Gloor P. 1960. Amygdala. In Handbook of Physiology. Section 1, Neurophysiology, ed. J Field, HW Magoun, WE Hall, 2:1395-420. Washington, DC: Am. Physiol. Soc.

Goddard GV. 1964. Functions of the amygdala. Psychol. Bull. 62:89-109

Goldstein LE, Rasmusson AM, Bunney BS, Roth RH. 1996. Role of the amygdala in the coordination of behavioral, neuroendocrine, and prefrontal cortical monoamine responses to psychological stress in the rat. J. Neurosci. 16:4787-98

Good M, Honey RC. 1997. Dissociable effects of selective lesions to hippocampal subsystems on exploratory behavior, contextual learning, and spatial learning. Behav. Neurosci. 111:487-93

Goosens KA, Holt W, Maren S. 2000. A role for amygdaloid PKA and PKC in the acquisition of long-term conditional fear memories in rats. Behav. Brain Res. 114:145-52

Grover LM, Teyler TJ. 1990. Two components of long-term potentiation induced by different patterns of afferent activation. Nature 347:477-79

Guarraci FA, Frohardt RJ, Kapp BS. 1999. Amygdaloid D1 dopamine receptor involvement in Pavlovian fear conditioning. Brain Res. 827:28-40

Haralambous T, Westbrook RF. 1999. An infusion of bupivacaine into the nucleus accumbens disrupts the acquisition but not the expression of contextual fear conditioning. Behav. Neurosci. 113:925-40

Heinbockel T, Pape HC. 2000. Input-specific long-term depression in the lateral amygdala evoked by theta frequency stimulation.

J. Neurosci. 20:RC68

Heldt SA, Falls WA. 1998. Destruction of the auditory thalamus disrupts the production of fear but not the inhibition of fear conditioned to an auditory stimulus. Brain Res. 813:27482

Helmstetter FJ. 1992. The amygdala is essential for the expression of conditional hypoalgesia. Behav. Neurosci. 106:518-28

Helmstetter FJ, Bellgowan PS. 1994. Effects of muscimol applied to the basolateral amygdala on acquisition and expression of contextual fear conditioning in rats. Behav. Neurosci. 108:1005-9

Hirsh R. 1974. The hippocampus and contextual retrieval of information from memory: a theory. Behav. Biol. 12:421-44

Hitchcock J, Davis M. 1986. Lesions of the 
amygdala, but not of the cerebellum or red nucleus, block conditioned fear as measured with the potentiated startle paradigm. Behav. Neurosci. 100:11-22

Holland PC, Bouton ME. 1999. Hippocampus and context in classical conditioning. Curr. Opin. Neurobiol. 9:195-202

Holland PC, Gallagher M. 1999. Amygdala circuitry in attentional and representational processes. Trends Cogn. Sci. 3:65-73

Holt W, Maren S. 1999. Muscimol inactivation of the dorsal hippocampus impairs contextual retrieval of fear memory. J. Neurosci. 19:9054-62

Honey RC, Good M. 1993. Selective hippocampal lesions abolish the contextual specificity of latent inhibition and conditioning. Behav. Neurosci. 107:23-33

Honey RC, Good M. 2000. Associative components of recognition memory. Curr. Opin. Neurobiol. 10:200-4

Horvath FE. 1963. Effects of basolateral amygdalectomy on three types of avoidance behavior in cats. J. Comp. Physiol. Psychol. 56:380-89

Huang YY, Kandel ER. 1998. Postsynaptic induction and PKA-dependent expression of LTP in the lateral amygdala. Neuron 21:16978

Huang YY, Martin KC, Kandel ER. 2000. Both protein kinase A and mitogen-activated protein kinase are required in the amygdala for the macromolecular synthesis-dependent late phase of long-term potentiation. J. Neurosci. 20:6317-25

Huerta PT, Sun LD, Wilson MA, Tonegawa S. 2000. Formation of temporal memory requires NMDA receptors within CA1 pyramidal neurons. Neuron 25:473-80

Impey S, Smith DM, Obrietan K, Donahue R, Wade C, et al. 1998. Stimulation of cAMP response element (CRE)-mediated transcription during contextual learning. Nat. Neurosci. 1:595-601

Iwata J, Chida K, LeDoux JE. 1987. Cardiovascular responses elicited by stimulation of neurons in the central amygdaloid nucleus in awake but not anesthetized rats resemble conditioned emotional responses. Brain Res. 418:183-88

Iwata J, LeDoux JE, Meeley MP, Arneric S, Reis DJ. 1986. Intrinsic neurons in the amygdaloid field projected to by the medial geniculate body mediate emotional responses conditioned to acoustic stimuli. Brain Res. 383:195-214

Izquierdo I, Medina JH. 1995. Correlation between the pharmacology of long-term potentiation and the pharmacology of memory. Neurobiol. Learn. Mem. 63:19-32

Kapp BS, Gallagher M, Holmquist BK, Theall CL. 1978. Retrograde amnesia and hippocampal stimulation: dependence upon the nature of associations formed during conditioning. Behav. Biol. 24:1-23

Kapp BS, Gallagher M, Underwood MD, McNall CL, Whitehorn D. 1982. Cardiovascular responses elicited by electrical stimulation of the amygdala central nucleus in the rabbit. Brain Res. 234:251-62

Kellicutt MH, Schwartzbaum JS. 1963. Formation of a conditioned emotional response (CER) following lesions of the amygdaloid complex in rats. Psychol. Rep. 12:351-58

Killcross S, Robbins TW, Everitt BJ. 1997. Different types of fear-conditioned behaviour mediated by separate nuclei within amygdala. Nature 388:377-80

Kim JJ, DeCola JP, Landeira-Fernandez J, Fanselow MS. 1991. N-methyl-D-aspartate receptor antagonist APV blocks acquisition but not expression of fear conditioning. $\mathrm{Be}$ hav. Neurosci. 105:126-33

Kim JJ, Fanselow MS. 1992. Modality-specific retrograde amnesia of fear. Science 256:67577

Kim JJ, Fanselow MS, DeCola JP, LandeiraFernandez J. 1992. Selective impairment of long-term but not short-term conditional fear by the N-methyl-D-aspartate antagonist APV. Behav. Neurosci. 106:591-96

Kim JJ, Rison RA, Fanselow MS. 1993a. Effects of amygdala, hippocampus, and periaqueductal gray lesions on short- and 
long-term contextual fear. Behav. Neurosci. 107:1093-98

Kim M, Campeau S, Falls WA, Davis M. 1993b. Infusion of the non-NMDA receptor antagonist CNQX into the amygdala blocks the expression of fear-potentiated startle. Behav. Neural Biol. 59:5-8

Kim M, Davis M. 1993. Lack of a temporal gradient of retrograde amnesia in rats with amygdala lesions assessed with the fearpotentiated startle paradigm. Behav. Neurosci. 107:1088-92

King FA. 1958. Effect of septal and amygdaloid lesions on emotional behaviour and conditioned avoidance responses in the rat. J. Nerv. Ment. Dis. 126:57-63

Kiyama Y, Manabe T, Sakimura K, Kawakami $\mathrm{F}$, Mori H, et al. 1998. Increased thresholds for long-term potentiation and contextual learning in mice lacking the NMDA-type glutamate receptor epsilon1 subunit. J. Neurosci. 18:6704-12

Klüver H, Bucy PC. 1937. "Psychic blindness" and other symptoms following bilateral temporal lobectomy in rhesus monkeys. Am. J. Physiol. 119:352-53

Krasne FB, Glanzman DL. 1995. What we can learn from invertebrate learning. Annu. Rev. Psychol. 46:585-624

Krettek JE, Price JL. 1978. A description of the amygdaloid complex in the rat and cat with observations on intra-amygdaloid axonal connections. J. Comp. Neurol. 178:25579

LaBar KS, Gatenby JC, Gore JC, LeDoux JE, Phelps EA. 1998. Human amygdala activation during conditioned fear acquisition and extinction: a mixed-trial fMRI study. Neuron 20:937-45

LaBar KS, LeDoux JE, Spencer DD, Phelps EA. 1995. Impaired fear conditioning following unilateral temporal lobectomy in humans. J. Neurosci. 15:6846-55

LeDoux JE. 1995. Emotion: clues from the brain. Annu. Rev. Psychol. 46:209-35

LeDoux JE. 2000. Emotion circuits in the brain. Annu. Rev. Neurosci. 23:155-84
LeDoux JE, Cicchetti P, Xagoraris A, Romanski LM. 1990. The lateral amygdaloid nucleus: sensory interface of the amygdala in fear conditioning. J. Neurosci. 10:106269

LeDoux JE, Iwata J, Cicchetti P, Reis DJ. 1988. Different projections of the central amygdaloid nucleus mediate autonomic and behavioral correlates of conditioned fear. $J$. Neurosci. 8:2517-29

LeDoux JE, Sakaguchi A, Iwata J, Reis DJ. 1986. Interruption of projections from the medial geniculate body to an archineostriatal field disrupts the classical conditioning of emotional responses to acoustic stimuli. Neuroscience 17:615-27

Lee H, Kim JJ. 1998. Amygdalar NMDA receptors are critical for new fear learning in previously fear-conditioned rats. J. Neurosci. 18:8444-54

Lee Y, Walker D, Davis M. 1996. Lack of a temporal gradient of retrograde amnesia following NMDA-induced lesions of the basolateral amygdala assessed with the fear-potentiated startle paradigm. Behav. Neurosci. 110:83639

Li H, Weiss SR, Chuang DM, Post RM, Rogawski MA. 1998. Bidirectional synaptic plasticity in the rat basolateral amygdala: characterization of an activity-dependent switch sensitive to the presynaptic metabotropic glutamate receptor antagonist 2S-alpha-ethylglutamic acid. J. Neurosci. 18:1662-70

Li XF, Phillips R, LeDoux JE. 1995. NMDA and non-NMDA receptors contribute to synaptic transmission between the medial geniculate body and the lateral nucleus of the amygdala. Exp. Brain Res. 105:87-100

Liang KC, McGaugh JL, Martinez J Jr, Jensen RA, Vasquez BJ, et al. 1982. Post-training amygdaloid lesions impair retention of an inhibitory avoidance response. Behav. Brain Res. 4:237-49

Malkani S, Rosen JB. 2000. Specific induction of early growth response gene 1 in the lateral nucleus of the amygdala following 
contextual fear conditioning in rats. Neuroscience 97:693-702

Maren S. 1996. Synaptic transmission and plasticity in the amygdala. An emerging physiology of fear conditioning circuits. $\mathrm{Mol}$. Neurobiol. 13:1-22

Maren S. 1997. Arousing the LTP and learning debate. Behav. Brain Sci. 20:622-23

Maren S. 1998. Overtraining does not mitigate contextual fear conditioning deficits produced by neurotoxic lesions of the basolateral amygdala. J. Neurosci. 18:3088-97

Maren S. 1999a. Long-term potentiation in the amygdala: a mechanism for emotional learning and memory. Trends Neurosci. 22:56167

Maren S. 1999b. Neurotoxic basolateral amygdala lesions impair learning and memory but not the performance of conditional fear in rats. J. Neurosci. 19:8696-703

Maren S. 1999c. Neurotoxic or electrolytic lesions of the ventral subiculum produce deficits in the acquisition and expression of Pavlovian fear conditioning in rats. Behav. Neurosci. 113:283-90

Maren S. 2000. Reply to Vazdarjanova. Trends Neurosci. 23:345-46

Maren S. 2001a. Auditory fear conditioning increases CS-elicited spike firing in lateral amygdala neurons even after extensive overtraining. Eur. J. Neurosci. In press

Maren S. 2001b. Multiple roles for synaptic plasticity in Pavlovian fear conditioning. In Neuronal Mechanisms of Memory Formation, ed. C Holscher, pp. 77-99. Cambridge: Cambridge Univ. Press

Maren S, Aharonov G, Fanselow MS. 1996a. Retrograde abolition of conditional fear after excitotoxic lesions in the basolateral amygdala of rats: absence of a temporal gradient. Behav. Neurosci. 110:718-26

Maren S, Aharonov G, Fanselow MS. 1997. Neurotoxic lesions of the dorsal hippocampus and Pavlovian fear conditioning in rats. Behav. Brain Res. 88:261-74

Maren S, Aharonov G, Stote DL, Fanselow MS. 1996b. N-methyl-D-aspartate recep- tors in the basolateral amygdala are required for both acquisition and expression of conditional fear in rats. Behav. Neurosci. 110:1365-74

Maren S, Anagnostaras SG, Fanselow MS. 1998. The startled seahorse: Is the hippocampus necessary for contextual fear conditioning? Trends Cogn. Sci. 2:39-42

Maren S, Baudry M. 1995. Properties and mechanisms of long-term synaptic plasticity in the mammalian brain: Relationships to learning and memory. Neurobiol. Learn. Mem. 63:1-18

Maren S, DeCola JP, Fanselow MS. 1994a. Water deprivation enhances fear conditioning to contextual, but not discrete, conditional stimuli in rats. Behav. Neurosci. 108:645-49

Maren S, DeCola JP, Swain RA, Fanselow MS, Thompson RF. 1994b. Parallel augmentation of hippocampal long-term potentiation, theta rhythm, and contextual fear conditioning in water-deprived rats. Behav. Neurosci. 108:44-56

Maren S, De Oca B, Fanselow MS. 1994c. Sex differences in hippocampal long-term potentiation (LTP) and Pavlovian fear conditioning in rats: positive correlation between LTP and contextual learning. Brain Res. 661:25-34

Maren S, Fanselow MS. 1995. Synaptic plasticity in the basolateral amygdala induced by hippocampal formation stimulation in vivo. J. Neurosci. 15:7548-64

Maren S, Fanselow MS. 1996. The amygdala and fear conditioning: Has the nut been cracked? Neuron 16:237-40

Maren S, Fanselow MS. 1997. Electrolytic lesions of the fimbria/fornix, dorsal hippocampus, or entorhinal cortex produce anterograde deficits in contextual fear conditioning in rats. Neurobiol. Learn. Mem. 67:142-49

Maren S, Fanselow MS. 1998. Appetitive motivational states differ in their ability to augment aversive fear conditioning in rats (Rattus norvegicus). J. Exp. Psychol.: Anim. Behav. Process. 24:369-73

Maren S, Holt W. 2000. The hippocampus 
and contextual memory retrieval in Pavlovian conditioning. Behav. Brain Res. 110:97-108

Maren S, Poremba A, Gabriel M. 1991. Basolateral amygdaloid multi-unit neuronal correlates of discriminative avoidance learning in rabbits. Brain Res. 549:311-16

Martin SJ, Grimwood PD, Morris RG. 2000. Synaptic plasticity and memory: an evaluation of the hypothesis. Annu. Rev. Neurosci. 23:649-711

Mayford M, Bach ME, Huang YY, Wang L, Hawkins RD, et al. 1996. Control of memory formation through regulated expression of a CaMKII transgene. Science 274:1678-83

McCabe PM, McEchron MD, Green EJ, Schneiderman N. 1993. Electrolytic and ibotenic acid lesions of the medial subnucleus of the medial geniculate prevent the acquisition of classically conditioned heart rate to a single acoustic stimulus in rabbits. Brain Res. 619:291-98

McDonald AJ. 1998. Cortical pathways to the mammalian amygdala. Prog. Neurobiol. 55:257-332

McEchron MD, Bouwmeester H, Tseng W, Weiss C, Disterhoft JF. 1998. Hippocampectomy disrupts auditory trace fear conditioning and contextual fear conditioning in the rat. Hippocampus 8:638-46

McEchron MD, Green EJ, Winters RW, Nolen TG, Schneiderman N, et al. 1996. Changes of synaptic efficacy in the medial geniculate nucleus as a result of auditory classical conditioning. J. Neurosci. 16:1273-83

McEchron MD, McCabe PM, Green EJ, Llabre MM, Schneiderman N. 1995. Simultaneous single unit recording in the medial nucleus of the medial geniculate nucleus and amygdaloid central nucleus throughout habituation, acquisition, and extinction of the rabbit's classically conditioned heart rate. Brain Res. 682:157-66

McGaugh JL. 2000. Memory-a century of consolidation. Science 287:248-51

McNish KA, Gewirtz JC, Davis M. 1997. Evidence of contextual fear after lesions of the hippocampus: a disruption of freezing but not fear-potentiated startle. J. Neurosci. 17:9353-60

McNish KA, Gewirtz JC, Davis M. 2000. Disruption of contextual freezing, but not contextual blocking of fear-potentiated startle, after lesions of the dorsal hippocampus. $\mathrm{Be}$ hav. Neurosci. 114:64-76

McKernan MG, Shinnick-Gallagher P. 1997. Fear conditioning induces a lasting potentiation of synaptic currents in vitro. Nature 390:607-11

Meunier M, Bachevalier J, Murray EA, Malkova L, Mishkin M. 1999. Effects of aspiration versus neurotoxic lesions of the amygdala on emotional responses in monkeys. Eur. J. Neurosci. 11:4403-18

Miserendino MJ, Sananes CB, Melia KR, Davis M. 1990. Blocking of acquisition but not expression of conditioned fear-potentiated startle by NMDA antagonists in the amygdala. Nature 345:716-18

Morgan MA, LeDoux JE. 1995. Differential contribution of dorsal and ventral medial prefrontal cortex to the acquisition and extinction of conditioned fear in rats. Behav. Neurosci. 109:681-88

Morgan MA, Romanski LM, LeDoux JE. 1993. Extinction of emotional learning: contribution of medial prefrontal cortex. Neurosci. Lett. 163:109-13

Morris JS, Frith CD, Perrett DI, Rowland D, Young AW, et al. 1996. A differential neural response in the human amygdala to fearful and happy facial expressions. Nature 383:812-15

Muller J, Corodimas KP, Fridel Z, LeDoux JE. 1997. Functional inactivation of the lateral and basal nuclei of the amygdala by muscimol infusion prevents fear conditioning to an explicit conditioned stimulus and to contextual stimuli. Behav. Neurosci. 111:68391

Nachman M, Ashe JH. 1974. Effects of basolateral amygdala lesions on neophobia, learned taste aversions, and sodium appetite in rats. J. Comp. Physiol. Psychol. 87:622-43

Nader K, LeDoux JE. 1999. Inhibition of the 
mesoamygdala dopaminergic pathway impairs the retrieval of conditioned fear associations. Behav. Neurosci. 113:891-901

Nader K, Schafe GE, LeDoux JE. 2000. Fear memories require protein synthesis in the amygdala for reconsolidation after retrieval. Nature 406:722-26

Pare D, Collins DR. 2000. Neuronal correlates of fear in the lateral amygdala: multiple extracellular recordings in conscious cats. J. Neurosci. 20:2701-10

Pavlov IP. 1927. Conditioned Reflexes: An Investigation of the Physiological Activity of the Cerebral Cortex. London: Oxford Univ. Press

Phillips ML, Young AW, Senior C, Brammer M, Andrew C, et al. 1997. A specific neural substrate for perceiving facial expressions of disgust. Nature 389:495-98

Phillips RG, LeDoux JE. 1992. Differential contribution of amygdala and hippocampus to cued and contextual fear conditioning. Behav. Neurosci. 106:274-85

Phillips RG, LeDoux JE. 1994. Lesions of the dorsal hippocampal formation interfere with background by not foreground contextual fear conditioning. Learn. Mem. 1:34-44

Phillips RG, LeDoux JE. 1995. Lesions of the fornix but not the entorhinal or perirhinal cortex interfere with contextual fear conditioning. J. Neurosci. 15:5308-15

Pitkanen A, Savander V, LeDoux JE. 1997. Organization of intra-amygdaloid circuitries in the rat: an emerging framework for understanding functions of the amygdala. Trends Neurosci. 20:517-23

Poremba A, Gabriel M. 1999. Amygdala neurons mediate acquisition but not maintenance of instrumental avoidance behavior in rabbits. J. Neurosci. 19:9635-41

Pugh CR, Tremblay D, Fleshner M, Rudy JW. 1997. A selective role for corticosterone in contextual-fear conditioning. Behav. Neurosci. 111:503-11

Quirk GJ, Armony JL, LeDoux JE. 1997. Fear conditioning enhances different temporal components of tone-evoked spike trains in auditory cortex and lateral amygdala. Neuron 19:613-24

Quirk GJ, Repa C, LeDoux JE. 1995. Fear conditioning enhances short-latency auditory responses of lateral amygdala neurons: parallel recordings in the freely behaving rat. Neuron 15:1029-39

Quirk GJ, Russo GK, Barron JL, Lebron K. 2000. The role of ventromedial prefrontal cortex in the recovery of extinguished fear. J. Neurosci. 20:6225-31

Rammes G, Steckler T, Kresse A, Schutz G, Zieglgansberger W, et al. 2000. Synaptic plasticity in the basolateral amygdala in transgenic mice expressing dominantnegative cAMP response element-binding protein (CREB) in forebrain. Eur. J. Neurosci. 12:2534-46

Rampon C, Tang YP, Goodhouse J, Shimizu E, Kyin M, et al. 2000. Enrichment induces structural changes and recovery from nonspatial memory deficits in CA1 NMDAR1knockout mice. Nat. Neurosci. 3:238-44

Rescorla RA. 1988. Pavlovian conditioning. It's not what you think it is. Am. Psychol. 43:15160

Richmond MA, Yee BK, Pouzet B, Veenman L, Rawlins JN, et al. 1999. Dissociating context and space within the hippocampus: effects of complete, dorsal, and ventral excitotoxic hippocampal lesions on conditioned freezing and spatial learning. Behav. Neurosci. 113:1189-203

Riedel G, Harrington NR, Hall G, Macphail EM. 1997. Nucleus accumbens lesions impair context, but not cue, conditioning in rats. NeuroReport 8:2477-81

Robinson E. 1963. The effect of amygdalectomy on fear-motivated behavior in rats. $J$. Comp. Physiol. Psychol. 56:814-20

Rogan MT, LeDoux JE. 1995. LTP is accompanied by commensurate enhancement of auditory-evoked responses in a fear conditioning circuit. Neuron 15:127-36

Rogan MT, LeDoux JE. 1996. Emotion: systems, cells, synaptic plasticity. Cell 85:46975 
Rogan MT, Staubli UV, LeDoux JE. 1997a. AMPA receptor facilitation accelerates fear learning without altering the level of conditioned fear acquired. J. Neurosci. 17:592835

Rogan MT, Staubli UV, LeDoux JE. 1997b. Fear conditioning induces associative longterm potentiation in the amygdala. Nature 390:604-7

Romanski LM, Clugnet MC, Bordi F, LeDoux JE. 1993. Somatosensory and auditory convergence in the lateral nucleus of the amygdala. Behav. Neurosci. 107:444-50

Romanski LM, LeDoux JE. 1992. Equipotentiality of thalamo-amygdala and thalamocortico-amygdala circuits in auditory fear conditioning. J. Neurosci. 12:4501-9

Roozendaal B, Koolhaas JM, Bohus B. 1991. Central amygdala lesions affect behavioral and autonomic balance during stress in rats. Physiol. Behav. 50:777-81

Rosen JB, Fanselow MS, Young SL, Sitcoske M, Maren S. 1998. Immediate-early gene expression in the amygdala following footshock stress and contextual fear conditioning. Brain Res. 796:132-42

Rosen JB, Hitchcock JM, Miserendino MJ, Falls WA, Campeau S, et al. 1992. Lesions of the perirhinal cortex but not of the frontal, medial prefrontal, visual, or insular cortex block fear-potentiated startle using a visual conditioned stimulus. J. Neurosci. 12:462433

Rosen JB, Schulkin J. 1998. From normal fear to pathological anxiety. Psychol. Rev. 105:325-50

Rudy JW. 1993. Contextual conditioning and auditory cue conditioning dissociate during development. Behav. Neurosci. 107:887-91

Rudy JW. 1996. Scopolamine administered before and after training impairs both contextual and auditory-cue fear conditioning. Neurobiol. Learn. Mem. 65:73-81

Rudy JW, Kuwagama K, Pugh CR. 1999. Isolation reduces contextual but not auditory-cue fear conditioning: a role for endogenous opioids. Behav. Neurosci. 113:316-23
Rudy JW, O'Reilly RC. 1999. Contextual fear conditioning, conjunctive representations, pattern completion, and the hippocampus. Behav. Neurosci. 113:867-80

Sacchetti B, Lorenzini CA, Baldi E, Tassoni G, Bucherelli C. 1999. Auditory thalamus, dorsal hippocampus, basolateral amygdala, and perirhinal cortex role in the consolidation of conditioned freezing to context and to acoustic conditioned stimulus in the rat. J. Neurosci. 19:9570-78

Sananes CB, Davis M. 1992. N-methyl-Daspartate lesions of the lateral and basolateral nuclei of the amygdala block fear-potentiated startle and shock sensitization of startle. Behav. Neurosci. 106:72-80

Schafe GE, Nadel NV, Sullivan GM, Harris A, LeDoux JE. 1999. Memory consolidation for contextual and auditory fear conditioning is dependent on protein synthesis, PKA, and MAP kinase. Learn. Mem. 6:97-110

Selden NR, Everitt BJ, Jarrard LE, Robbins TW. 1991. Complementary roles for the amygdala and hippocampus in aversive conditioning to explicit and contextual cues. Neuroscience 42:335-50

Shi C, Davis M. 1999. Pain pathways involved in fear conditioning measured with fear-potentiated startle: lesion studies. J. Neurosci. 19:420-30

Shors TJ, Matzel LD. 1997. Long-term potentiation: What's learning got to do with it? Behav. Brain Sci. 20:597-634

Squire LR, Zola Morgan S. 1991. The medial temporal lobe memory system. Science 253:1380-86

Supple W Jr, Kapp BS. 1989. Response characteristics of neurons in the medial component of the medial geniculate nucleus during Pavlovian differential fear conditioning in rabbits. Behav. Neurosci. 103:1276-86

Swanson LW, Petrovich GD. 1998. What is the amygdala? Trends Neurosci. 21:323-31

Tang YP, Shimizu E, Dube GR, Rampon C, Kerchner GA, et al. 1999. Genetic enhancement of learning and memory in mice. Nature 401:63-69 
Thompson RF, Krupa DJ. 1994. Organization of memory traces in the mammalian brain. Annu. Rev. Neurosci. 17:519-49

Tomaz C, Dickinson-Anson H, McGaugh JL. 1991. Amygdala lesions block the amnestic effects of diazepam. Brain Res. 568:8591

Treit D, Menard J. 1997. Dissociations among the anxiolytic effects of septal, hippocampal, and amygdaloid lesions. Behav. Neurosci. 111:653-58

Treit D, Pesold C, Rotzinger S. 1993. Dissociating the anti-fear effects of septal and amygdaloid lesions using two pharmacologically validated models of rat anxiety. Behav. Neurosci. 107:770-85

Tsien JZ, Huerta PT, Tonegawa S. 1996. The essential role of hippocampal CA1 NMDA receptor-dependent synaptic plasticity in spatial memory. Cell 87:1327-38

Vazdarjanova A. 2000. Does the basolateral amygdala store memories for emotional events? Trends Neurosci. 23:345

Vazdarjanova A, McGaugh JL. 1998. Basolateral amygdala is not critical for cognitive memory of contextual fear conditioning. Proc. Natl. Acad. Sci. USA 95:15003-7

Vazdarjanova A, McGaugh JL. 1999. Basolateral amygdala is involved in modulating consolidation of memory for classical fear conditioning. J. Neurosci. 19:6615-22

Vouimba RM, Garcia R, Baudry M, Thompson RF. 2000. Potentiation of conditioned freezing following dorsomedial prefrontal cortex lesions does not interfere with fear reduction in mice. Behav. Neurosci. 114:720-24

Vouimba RM, Garcia R, Jaffard R. 1998. Opposite effects of lateral septal LTP and lateral septal lesions on contextual fear conditioning in mice. Behav. Neurosci. 112:875-84

Walker DL, Davis M. 1997. Double dissociation between the involvement of the bed nucleus of the stria terminalis and the central nucleus of the amygdala in startle increases produced by conditioned versus unconditioned fear. J. Neurosci. 17:9375-83

Wang SJ, Gean PW. 1999. Long-term depres- sion of excitatory synaptic transmission in the rat amygdala. J. Neurosci. 19:10656-63

Watkins LR, Wiertelak EP, Maier SF. 1993. The amygdala is necessary for the expression of conditioned but not unconditioned analgesia.

Behav. Neurosci. 107:402-5

Watson JB. 1920. Experimental Investigation of Babies. Chicago: Stoelting

Watson JB, Rayner R. 1920. Conditioned emotional reactions. J. Exp. Psychol. 3:1-14

Weeber EJ, Atkins CM, Selcher JC, Varga AW, Mirnikjoo B, et al. 2000. A role for the beta isoform of protein kinase $\mathrm{C}$ in fear conditioning. J. Neurosci. 20:5906-14

Weinberger NM. 1993. Learning-induced changes of auditory receptive fields. Curr. Opin. Neurobiol. 3:570-77

Weinberger NM. 1995. Dynamic regulation of receptive fields and maps in the adult sensory cortex. Annu. Rev. Neurosci. 18:129-58

Weiskrantz L. 1956. Behavioral changes associated with ablation of the amygdaloid complex in monkeys. J. Comp. Physiol. Psychol. 49:381-91

Weisskopf MG, Bauer EP, LeDoux JE. 1999. L-type voltage-gated calcium channels mediate NMDA-independent associative longterm potentiation at thalamic input synapses to the amygdala. J. Neurosci. 19:1051219

Westbrook RF, Good AJ, Kiernan MJ. 1997. Microinjection of morphine into the nucleus accumbens impairs contextual learning in rats. Behav. Neurosci. 111:996-1013

Whalen PJ, Rauch SL, Etcoff NL, McInerney SC, Lee MB, et al. 1998. Masked presentations of emotional facial expressions modulate amygdala activity without explicit knowledge. J. Neurosci. 18:411-18

Wilensky AE, Schafe GE, LeDoux JE. 1999. Functional inactivation of the amygdala before but not after auditory fear conditioning prevents memory formation. J. Neurosci. 19:RC48

Wilensky AE, Schafe GE, LeDoux JE. 2000. The amygdala modulates memory consolidation of fear-motivated inhibitory avoidance 
learning but not classical fear conditioning. J. Neurosci. 20:7059-7066

Wilson A, Brooks DC, Bouton ME. 1995. The role of the rat hippocampal system in several effects of context in extinction. Behav. Neurosci. 109:828-36

Wolpe J. 1981. The dichotomy between classical conditioned and cognitively learned anxiety. J. Behav. Ther. Exp. Psychiatry 12:35-42

Young AW, Aggleton JP, Hellawell DJ, Johnson M, Broks P, et al. 1995. Face processing impairments after amygdalotomy. Brain 118:15-24

Young BJ, Leaton RN. 1996. Amygdala cen- tral nucleus lesions attenuate acoustic startle stimulus-evoked heart rate changes in rats. Behav. Neurosci. 110:228-37

Young SL, Bohenek DL, Fanselow MS. 1994. NMDA processes mediate anterograde amnesia of contextual fear conditioning induced by hippocampal damage: immunization against amnesia by context preexposure. Behav. Neurosci. 108:19-29

Zola Morgan S, Squire LR, Alvarez Royo P, Clower RP. 1991. Independence of memory functions and emotional behavior: separate contributions of the hippocampal formation and the amygdala. Hippocampus 1:207-20 